Article

\title{
Enhanced Arsenic(V) Removal on an Iron-Based Sorbent Modified by Lanthanum(III)
}

\author{
Sebastian Dudek *(i) and Dorota Kołodyńska \\ Department of Inorganic Chemistry, Institute of Chemical Sciences, Faculty of Chemistry, \\ Maria Curie-Skłodowska University, pl. Marii Curie-Skłodowskiej 2, 20-031 Lublin, Poland; \\ d.kolodynska@poczta.umcs.lublin.pl \\ * Correspondence: sebastian.dudek@poczta.umcs.lublin.pl; Tel.: +48-81-5375770
}

Received: 24 April 2020; Accepted: 29 May 2020; Published: 3 June 2020

\begin{abstract}
Modification of a commercial iron oxide ion exchanger (Arsen $X^{n p}$ ) was carried out to enhance the removal of arsenic $(\mathrm{V})$ ions. The modification consisted of the adsorption of lanthanum(III) ions on the Arsen $X^{n p}$ surface. After adsorption, the material was dried at $313 \mathrm{~K}$ to obtain the modified ion exchanger Arsen $\mathrm{X}^{\mathrm{nP}}$ - $\mathrm{La}(\mathrm{III})$. The modification process itself was tested for optimal $\mathrm{pH}$, kinetics, and equilibrium adsorption isotherm study. Accurate sorbent characteristics were made using, among others, SEM, FTIR, and nitrogen adsorption/desorption isotherms. Then, various tests were carried out to compare the adsorption properties of the modified and unmodified material. It turned out that the tested material was able to completely remove arsenic from an aqueous solution with an initial concentration of up to $50 \mathrm{mg} / \mathrm{dm}^{3}$. Without modification, it was not possible to reach the WHO recommended $10 \mu \mathrm{g} / \mathrm{dm}^{3}$ arsenic limit even at an initial concentration of $25 \mathrm{mg} / \mathrm{dm}^{3}$. Moreover, the maximum sorption capacity increased from 22.37 to $61.97 \mathrm{mg} / \mathrm{g}$ after modification (3 times greater than before modification). It is worth noting that the process of removing arsenic on Arsen $\mathrm{X}^{\mathrm{nP}}$ - $\mathrm{La}$ (III) is fast-equilibrium is reached after about $120 \mathrm{~min}$. Under almost neutral conditions, precipitation and adsorption can be the main mechanisms of $\mathrm{As}(\mathrm{V})$ removal. After modification, the removal capacity was enhanced by the co-precipitation and adsorption by exchange of the $\mathrm{OH}$ - group with arsenic ions. Such $\mathrm{La}(\mathrm{III})$ based adsorbent can be successfully applied in wastewater purification and displays superior performance for removing arsenic.
\end{abstract}

Keywords: arsenic removal; lanthanum; iron oxides; adsorption; Arsen $X^{\text {np }}$

\section{Introduction}

Arsenic is an element known for its toxicity. It is found in South and North America, Europe, Australia and Africa, but the largest problem occurs in the areas of southern and south-east Asia where the maximum permissible level of arsenic is largely exceeded [1,2]. Arsenic penetrates into water systems as a result of natural weathering processes, volcanic emissions, geochemical reactions or anthropogenic activities, e.g., fossil fuel combustion, the use of arsenic pesticides and herbicides, and mining activities $[3,4]$.

According to the World Health Organization (WHO) guidelines, the admissible content of arsenic in drinking water is $10 \mu \mathrm{g} / \mathrm{dm}^{3}$. Therefore, more than 100 million people around the world are at risk of its exposure. However, 45 million people from developing Asian countries are still exposed to arsenic concentration greater than $50 \mu \mathrm{g} / \mathrm{dm}^{3}$. Long-term consumption of arsenic contaminated water can lead to neurological disorders, skin pigment changes, vomiting and also kidney, lung or bladder cancer [5]. Therefore high-efficiency and cost-effective technologies have been needed to treat and remove arsenic from drinking water. 
In numerous available studies, adsorption has been chosen as the most appropriate method for solving the problem of water systems contaminated by arsenic(V). Adsorbents which combine the best advantages, i.e., low cost, great strength, and the ability to be used in changing environmental conditions, are desirable. Many authors decide to exploit ion exchangers based on iron oxides [6-8]. However, these adsorbents often have low adsorption capacity towards arsenic ions. Consequently, a lot of authors try to modify them in order to obtain greater adsorption. Moreover, to enhance sorption capacity and selectivity, immobilization of ligands with multi-coordinating active sites, ligands which are biomimetically relevant, complexes with low molecular weight and immobilizing of ethers, calixarenes, impregnation of metal ions, and preparation of reactive ion exchangers are proposed. In the paper by Jiang et al. [9], adsorption of arsenic(V) onto polystyrene-iron oxide $\mathrm{PS}_{-} \mathrm{Fe}_{3} \mathrm{O}_{4}$ sorbent was tested depending on the $\mathrm{pH}$ of the solution, arsenic concentration, and phase contact time. Additionally,

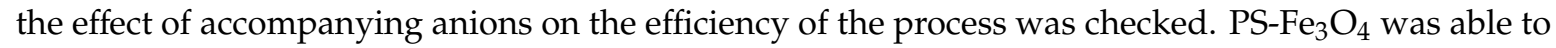
reach equilibrium faster and exhibited higher sorption capacity for arsenates $(\mathrm{V})$ than the unmodified $\mathrm{Fe}_{3} \mathrm{O}_{4}\left(139.3 \mathrm{mg} / \mathrm{g}-77.7 \%\right.$ higher than pure $\left.\mathrm{Fe}_{3} \mathrm{O}_{4}\right)$. Chloride and nitrate $(\mathrm{V})$ anions, unlike $\mathrm{PO}_{4}{ }^{3-}$ and $\mathrm{SiO}_{3}{ }^{2-}$ ions, did not have a major impact on the sorption process. The discussed hybrid material was effectively separated from the water in the presence of a weak magnetic field $(<0.035 \mathrm{~T})$. In addition, it could be reused after regenerating the sorbent with $\mathrm{NaOH}$ solution.

This type of adsorbent containing inbuilt iron nanooxide molecules of the goethite structure-Purolite Arsen $\mathrm{X}^{\mathrm{np}}$ —is produced on a commercial scale. In the production process, iron oxide was distributed in the pores of the above-mentioned ion exchanger as a layer of a few nanometers thickness. However, in order to increase the surface effectiveness of such adsorbents, other modification methods can be applied. One of them could be modification of the $\mathrm{R}-\mathrm{N}\left(\mathrm{CH}_{3}\right)_{3}(\mathrm{OH}) / \mathrm{FeO}(\mathrm{OH})$ structure by trivalent or tetravalent ions. In the study by He et al. [10], an iron-cerium bimetal oxide adsorbent was applied for $\mathrm{As}(\mathrm{V})$ removal sorption capacity $(149.84 \mathrm{mg} / \mathrm{g})$ more successfully than many reported adsorbents. The bimetal oxide adsorbents were prepared by a co- precipitation method. Based on the XPS results, it was proved that the obtained sorbent was composed of hydroxyl (30.8\%) and $\mathrm{CeO}_{2}$ and $\mathrm{Fe}_{3} \mathrm{O}_{4}(12.6 \%$ and $19.6 \%)$. Therefore, both the integral area of the As-O band and the As(V) adsorption capacity increased almost linearly with the decrease in the integral area of $\mathrm{M}-\mathrm{OH}$ bands, proving that the adsorption of $\mathrm{As}(\mathrm{V})$ is mainly realized through the mechanism of quantitative ligand exchange. Analogous results were obtained using Fourier transform infrared spectra where it was revealed that in $\mathrm{As}(\mathrm{V})$ adsorption $\mathrm{M}-\mathrm{OH}$ groups play an important role.

In this study, attempts have been made to enhance the removal of arsenate ions onto Arsen $X^{n p}$ modified by $\mathrm{La}(\mathrm{III})$ in order to reduce their amount in the environment. The sorbent was prepared by adsorption of lanthanum(III) ions under specific conditions and then for arsenic(V) removal. Lanthanum is one of the cheapest rare-earth elements. Comparison of the sorption properties of the raw Arsen $X^{\mathrm{np}}$ and the modified sorbent Arsen $X^{\mathrm{np}}-\mathrm{La}(\mathrm{III})$ was made. There are studies in which various sorbents have been modified with lanthanum. Jang et al. [11] synthesized the highly ordered mesoporous silica, SBA-15, and incorporated various amounts of lanthanum oxide into it. Then, they applied the material for arsenate removal in the adsorption process. Tan et al. [12] fabricated a novel adsorbent CSN-La of lanthanum immobilized on electrospun chitosan nanofiber (CSN). The saturated adsorption capacity of CSN-La reached up to $83.6 \mathrm{mg} \mathrm{As}(\mathrm{V}) / \mathrm{g}$, which was significantly higher than that of CSN. The exhausted CSN-La could be repeatedly used after being eluted by sodium hydroxide solution. In the paper by Lingamdinne et al. [13], the surface of graphene oxide was functionalized with lanthanum to produce porous flowered graphene oxide-lanthanumfluoride (GO-LaF) nanocomposite. The adsorption results obtained under different conditions suggest that $\mathrm{As}(\mathrm{V})$ adsorption onto GO-LaF occurs through mixed processes such as electrostatic, ion-exchange, and surface complexation. However, a study, in which a commercially available sorbent based on iron oxide was modified with lanthanum, does not exist. A successful modification can help supply safe arsenic-free drinking water. Moreover, the multiple use of the same material can reduce significantly the costs of the groundwater treatment process. 


\section{Materials and Methods}

\subsection{Modification of the Adsorbent}

In order to increase $\mathrm{As}(\mathrm{V})$ sorption capacity, the modification of the sorbent consisted in adsorption of lanthanum(III) ions from aqueous solution $\left(\mathrm{t}=6 \mathrm{~h}, \mathrm{c}_{\mathrm{o}}=100 \mathrm{mg} / \mathrm{dm}^{3}\right)$ and then drying the sorbent at $313 \mathrm{~K}$. In that way, Arsen $\mathrm{X}^{\mathrm{np}}$ modified with $\mathrm{La}$ (III) ions was obtained. To learn more about the sorbent modification process, the effects of $\mathrm{pH}$ and sorption kinetics of lanthanum were studied. Moreover, Langmuir and Freundlich isotherms were determined for this process. The abbreviation $X^{n p}$ will be used for the pure Arsen $X^{\mathrm{np}}$ sorbent, while $\mathrm{X}^{\mathrm{np}}$-La(III) for Arsen $\mathrm{X}^{\mathrm{np}}$ with adsorbed lanthanum(III) ions.

\subsection{Materials and Chemicals}

Purolite Arsen $X^{n p}$ (Purolite, Philadelphia, PA, USA) is a macroporous, selective resin based on polystyrene crosslinked with divinylbenzene skeleton with sulfonic groups and a unique structure of hydrated iron nanoparticles (designed to remove arsenic(V) and arsenic(III) ions). This ion exchanger is characterized by high durability and selectivity towards $\mathrm{Cu}(\mathrm{II}), \mathrm{Zn}(\mathrm{II}), \mathrm{Cr}(\mathrm{VI}), \mathrm{Cd}(\mathrm{II})$, and $\mathrm{Pb}$ (II) ions $[14,15]$. It is available on a commercial scale due to the finding of SenGupta and Cumbal (U.S. Patent US7291578B2 [16]) and used to impregnate strongly basic anion exchange resins with iron hydroxide nanoparticles. Next, the technology was further modified and commercialized by SolmeteX, Layne Christensen Company (The Woodlands, TX, USA), and Purolite International Ltd. Its physicochemical properties are collected in Table 1.

Table 1. Properties of Purolite Arsen Xnp.

\begin{tabular}{cc}
\hline Polymer Structure & Divinylbenzene Crosslinked with Polystyrene \\
\hline Matrix structure & Macroporous \\
Physical form and appearance & Reddish-brown spherical particles \\
Particle size range & $0.300-1.200 \mathrm{~mm}$ \\
Maximum working temperature & $80^{\circ} \mathrm{C}$ \\
Working pH range & $4-9$ \\
\hline
\end{tabular}

The point of zero charge $\left(\mathrm{pH}_{\mathrm{pzc}}\right)$ before and after the lanthanum(III) sorption of the sorbents was determined using the drift method [17]. The determination of $\mathrm{pH}_{\mathrm{pzc}}$ was conducted by adjusting the $\mathrm{pH}$ of $20 \mathrm{~mL} 0.01 \mathrm{M} \mathrm{NaCl}$ solution to a value between 2 and $11\left(\mathrm{pH}_{\mathrm{i}}\right) .0 .1 \mathrm{~g}$ of the sorbent was added and the final $\mathrm{pH}\left(\mathrm{pH}_{\mathrm{f}}\right)$ was measured after $6 \mathrm{~h}$ under agitation. The $\mathrm{pH}_{\mathrm{pzc}}$ is the point where $\mathrm{pH}_{\mathrm{i}}-\mathrm{pH}_{\mathrm{f}}=0$. The initial and final $\mathrm{pHs}$ were measured using the Radiometer PHM $84 \mathrm{pH}$ meter (Copenhagen, Denmark) with the glass REF 451 and calomel pHG 201-8 electrodes.

The morphology of the sorbent before and after the lanthanum(III) sorption was determined using scanning electron microscopy (SEM) (Tescan, Brno, Czech Republic) with an extended depth of field (EDF) function.

Using an ASAP 2405 analyzer (Micromeritics, Norcross, GA, USA), porous structure parameters of the sorbents were evaluated. These tests were aimed at determining nitrogen adsorption-desorption isotherms of the analyzed materials. The specific surface area was determined by the Brunauer-Emmet $\mathrm{t}$-Teller method as well as the total volume and pore size distribution according to the Barret-Joyner -Halenda model.

Infrared spectroscopy analysis with Fourier transformation was used to record the spectra of the analyzed adsorbents. $\mathrm{X}^{\mathrm{np}}$ and $\mathrm{X}^{\mathrm{np}}$ - $\mathrm{La}(\mathrm{III})$ before and after the $\mathrm{As}(\mathrm{V})$ sorption were tested by the attenuated total reflection method using the Agilent Cary 630 FTIR spectrometer. Thanks to this, it was possible to define the characteristic functional groups located on the surface of the material used. In the FTIR analyses, infrared radiation covered the wavenumber range of $4000-650 \mathrm{~cm}^{-1}$.

The solutions in the model wastewater were prepared for experiments by dissolving $\mathrm{La}\left(\mathrm{NO}_{3}\right)_{3} \cdot 6 \mathrm{H}_{2} \mathrm{O}$ and $\mathrm{Na}_{2} \mathrm{HAsO}_{4} \cdot 7 \mathrm{H}_{2} \mathrm{O}$ in water. The specific $\mathrm{pH}$ of the solutions was achieved 
by adding appropriate amounts of $1 \mathrm{M}$ hydrochloric acid and $1 \mathrm{M}$ sodium hydroxide. All chemicals applied were used at analytical purity and purchased from POCh (Gliwice, Poland).

\subsection{Batch Experiments}

\subsubsection{Sorbent Modification}

To examine lanthanum(III) adsorption depending on $\mathrm{pH}$ values, solutions containing $10 \mathrm{mg} / \mathrm{dm}^{3}$ of lanthanum(III) at $\mathrm{pH}$ in the range from 2 to 6 were prepared. $0.1 \mathrm{~g}$ of $\mathrm{X}^{\mathrm{np}}$ and $20 \mathrm{~cm}^{3}$ of lanthanum(III) solution at different $\mathrm{pH}$ values were added separately to $100 \mathrm{~cm}^{3}$ conical flasks. After that, the samples were shaken for $24 \mathrm{~h}\left(\mathrm{c}=10 \mathrm{mg} / \mathrm{dm}^{3}, \mathrm{pH}=2-6\right.$, shaking speed $180 \mathrm{rpm}$, temperature $\left.295 \mathrm{~K}\right)$. The ELPIN+ type 358A shaker (Lubawa, Poland) was used. After shaking, the solutions were separated from the sorbent by filtration on filter paper. After the experiment, the lanthanum(III) concentrations of the analyzed ions were determined using inductively coupled plasma optical emission spectrometry (ICP-OES) (720 ES, Varian, Palo Alto, CA, USA). The wavelength used for the analysis of La(III) was $333.749 \mathrm{~nm}$. The ICP-OES instrument was calibrated using the appropriate standards. To prepare all standards and blank samples, ultrapure nitric acid was used in order to avoid any matrix interference.

The sorption kinetics of lanthanum(III) was investigated using the static method. The solutions of lanthanum(III) were prepared at concentrations of 10, 50, and $100 \mathrm{mg} / \mathrm{dm}^{3}$ (and at the previously determined optimal $\mathrm{pH}$ value). $0.1 \mathrm{~g}$ of $\mathrm{X}^{\mathrm{np}}$ was added to Erlenmeyer flasks. $20 \mathrm{~cm}^{3}$ of the above-mentioned solutions was added to each flask and shaken for 1, 3, 5, 7, 10, 20, 30, 60, 120, 240, and $360 \mathrm{~min}$. After shaking, the samples were filtered on filter paper and the solutions were separated from the sorbent. Then, the concentrations of lanthanum(III) were determined using ICP-OES.

The amount of adsorbed lanthanum(III) ions $\left(q_{t}\right)$ was estimated from the following equation:

$$
q_{t}=\left(c_{0}-c_{t}\right) \times \frac{V}{m}
$$

where: $q_{t}$ is the amount of lanthanum(III) adsorbed at time $t(\mathrm{mg} / \mathrm{g}), c_{0}$ is the initial concentration of lanthanum(III) in the solution $\left(\mathrm{mg} / \mathrm{dm}^{3}\right), c_{t}$ is the concentration of lanthanum(III) in the solution after time $t\left(\mathrm{mg} / \mathrm{dm}^{3}\right), V$ is the volume of the solution containing lanthanum(III) ions $\left(\mathrm{dm}^{3}\right), m$ is the mass of sorbent (g).

The percentage of adsorption (\%S) is that of lanthanum(III) adsorbed on the adsorbent beads calculated from the following equation:

$$
\% S=\frac{\left(c_{0}-c_{t}\right)}{c_{0}} \times 100 \%
$$

The kinetic parameters of metal ions sorption onto the sorbent were determined using the pseudo-first order kinetic equation (PFO) and pseudo-second order equation (PSO) [18-20]:

$$
\begin{aligned}
\log \left(q_{e}-q_{t}\right) & =\log \left(q_{e}\right)-\frac{k_{1}}{2.303} \times t \\
\frac{t}{q_{t}} & =\frac{1}{k_{2} \times q_{e}^{2}}+\frac{t}{q_{e}}
\end{aligned}
$$

where: $q_{e}$ is the amount of lanthanum(III) adsorbed at equilib $\neg$ rium $(\mathrm{mg} / \mathrm{g}), q_{t}$ is the amount of lanthanum(III) adsorbed at time $t(\mathrm{mg} / \mathrm{g}), k_{1}$ and $k_{2}$ are the reaction rate constants of the pseudo-first order (1/min) and pseudo-second order ( $\mathrm{g} / \mathrm{mg} \mathrm{min})$.

The adsorption capacity of $X^{n p}$ towards lanthanum(III) ions was determined by the equilibrium adsorption isotherm study. The initial concentrations of $\mathrm{La}(\mathrm{III})$ ions were equal to 10, 50, 100, 150, 300 and $500 \mathrm{mg} / \mathrm{dm}^{3}(\mathrm{t}=6 \mathrm{~h}$, shaking speed $180 \mathrm{rpm}$, temperature $295 \mathrm{~K})$. 


\subsubsection{Influence of $\mathrm{pH}$}

The solutions of $25 \mathrm{mg} / \mathrm{dm}^{3} \mathrm{As}(\mathrm{V})$ ions were prepared to examine arsenic $(\mathrm{V})$ adsorption depending on the $\mathrm{pH}$ values. The same parameters were used as when testing the effect of $\mathrm{pH}$ on lanthanum(III) sorption, as described in Section 2.3.1. After the experiment, the concentrations of the analyzed ions and the sorption capacities were determined using the spectrophotometric method (Cary 60, Agilent Technologies) at a wavelength $870 \mathrm{~nm}$ by obtaining coloured $\mathrm{As}(\mathrm{V})$ complex compounds with ammonium molybdate. The UV-Vis instrument was calibrated using the appropriate standards.

\subsubsection{Kinetic Studies}

The arsenic $(\mathrm{V})$ sorption kinetics was investigated using the static method. The solutions of arsenate $(\mathrm{V})$ at concentrations of 25,50 , and $100 \mathrm{mg} / \mathrm{dm}^{3}\left(\mathrm{pH}\right.$ 6). $0.1 \mathrm{~g}$ of $X^{\mathrm{np}}$ were added to Erlenmeyer flasks. $20 \mathrm{~cm}^{3}$ of the above-mentioned solutions was added to each flask and shaken for 1,3,5, 7, 10, 20, 30, 60, 120, 240 and $360 \mathrm{~min}$ (shaking speed $180 \mathrm{rpm}$ ). The experiment was repeated for the $\mathrm{X}^{\mathrm{np}}$-La(III) sorbent and the results on the modified and unmodified $X^{\mathrm{np}}$ were compared. The laboratory water bath shaker Elpin+ type 357 (Elpin Plus, Lubawa, Poland) was used for the experiments. After shaking, the samples were filtered on filter paper and the solutions were separated from the sorbent. Then, the concentrations of arsenic $(V)$ ions were determined using the UV-Vis method (Cary 60, Agilent Technologies, Santa Clara, CA, USA), as described below.

The amount of adsorbed arsenic ions was estimated from Equation (1). The experimental data of $\mathrm{As}(\mathrm{V})$ kinetic studies was fitted to the PFO (Equation (3) and the PSO (Equation (4)) models.

\subsubsection{Equilibrium Adsorption Isotherm Study}

The adsorption capacity of $\mathrm{X}^{\mathrm{np}}$ towards arsenic $(\mathrm{V})$ ions was determined by the equilibrium adsorption isotherm study. The same study was carried out for $\mathrm{X}^{\mathrm{nP}}-\mathrm{La}(\mathrm{III})$. The initial concentrations of $\mathrm{As}(\mathrm{V})$ ions were equal to $25,50,100,150,300,500,750$, and $1000 \mathrm{mg} / \mathrm{dm}^{3}(\mathrm{t}=6 \mathrm{~h}$, shaking speed $180 \mathrm{rpm}$, temperature $295 \mathrm{~K}$ ). The adsorption data was fitted into both the Langmuir isotherm and the Freundlich isotherm, whose equations are presented below [18-20]:

$$
\begin{gathered}
q_{e}=\frac{q_{0} K_{L} c_{e}}{1+K_{L} c_{e}} \\
q_{e}=K_{F} c_{e}^{1 / n}
\end{gathered}
$$

where: $q_{0}$ is the maximum monolayer adsorption capacity $(\mathrm{mg} / \mathrm{g}) ; K_{L}$ is the Langmuir constant $\left(\mathrm{dm}^{3} / \mathrm{mg}\right)$; $c_{e}$ is the adsorbate concentration in the solution at equilibrium $\left(\mathrm{mg} / \mathrm{dm}^{3}\right) ; K_{F}$ is the Freundlich isotherm constant $(\mathrm{mg} / \mathrm{g}) ; n$ is the Freundlich exponent (degrees of sorption favourability and intensity) (-).

The two parameters $\left(K_{L}\right.$ and $\left.q_{e}\right)$ can be obtained using the slope and the intercept to characterize the adsorption process. The $R_{L}$ parameter is determined from the equation:

$$
R_{L}=\frac{1}{1+K_{L} c_{0}}
$$

\subsubsection{Desorption}

Three cycles of sorption and desorption of arsenate $(\mathrm{V})$ ions were carried out on $0.1 \mathrm{~g}$ of the modified and unmodified sorbent. Sorption was conducted from a solution with an initial arsenic concentration of $100 \mathrm{mg} / \mathrm{dm}^{3}$, volume $20 \mathrm{~cm}^{3}$, temperature $295 \mathrm{~K}, \mathrm{pH}$ 6, and shaking time $6 \mathrm{~h} \mathrm{(180} \mathrm{rpm).}$ The desorption conditions were identical, and the desorbing agent was $1 \mathrm{M} \mathrm{NaOH}$. One sorption and desorption cycle were also carried out for $\mathrm{NaOH}$ concentrations 0.05 and $0.2 \mathrm{M}$. After each sorption and desorption, the sorbent was separated from the solution and dried at a temperature of $313 \mathrm{~K}$. Then, the ion exchanger reusability was evaluated. 


\section{Results and Discussion}

\subsection{Sorbent Characterization}

The point of zero charge $\mathrm{pH}_{\mathrm{pzc}}$ of $\mathrm{X}^{\mathrm{np}}$ is equal to 8.38. After adsorption of lanthanum (III) ions, the $\mathrm{pH}_{\mathrm{pzc}}$ decreased to 7.21 (Figure 1). The $\mathrm{pH}_{\mathrm{pzc}}$ value of a given substance depends on the nature of the surface $[17,18]$. It means that $X^{n p}$ and $X^{n p}-\mathrm{La}(\mathrm{III})$ are able to exchange anions at a $\mathrm{pH}$ below 8.38 and 7.21, respectively. Analysing the adsorption data at different $\mathrm{pH}$ values in connection with the speciation distribution of the $\mathrm{As}(\mathrm{V})$ forms dependent on the $\mathrm{pH}_{\mathrm{a}}$ values as well as $\mathrm{pH}_{\mathrm{ZPC}} \mathrm{will}$ provide useful information about sorption mechanism. At $\mathrm{pH}>\mathrm{pH}_{\mathrm{ZPC}}$ or $\mathrm{pH}<\mathrm{pKa}$ the electrostatic repulsion reduces the adsorption when $\mathrm{pH}$ increases (at $\mathrm{pH}>\mathrm{pH} \mathrm{ZPC}_{\text {) }}$ or decrease (when $\mathrm{pH}<\mathrm{pKa}$ ). However, at $\mathrm{pKa}<\mathrm{pH}<\mathrm{pH}_{\mathrm{ZPC}}$ the electrostatic attraction is an important interaction. The solution $\mathrm{pH}$ affected largely the behaviour of the functional groups. If the number of negative groups decreases with the decreasing solution $\mathrm{pH}$, the surface becomes positively charged. Additionally, due to the high electrostatic repulsive forces involved in the adsorbent- adsorbate and adsorbate-adsorbate interactions, the adsorption capacity of $X^{n p}-\mathrm{La}(\mathrm{III})$ towards $\mathrm{As}(\mathrm{V})$ can be lower than when the solute is in its molecular form or if the solution $\mathrm{pH}$ is below $\mathrm{pH}_{\mathrm{ZPC}}$. Therefore, the maximum removal of arsenic oxyanions can be observed in the acidic systems. $\mathrm{pH}_{\mathrm{ZPC}}$ of $\mathrm{X}^{\mathrm{np}}$-La(III) was 7.21 therefore at $\mathrm{pH}$ lower than this value protonation proceeds thus negatively charged arsenic species can be attracted electrostatically. As was mentioned during the discussion the mechanism of As(V) removal is more complicated. For $\mathrm{As}(\mathrm{V})$, this indicates that the attractive interaction between the positively charged surface of adsorbents and anionic As(V) species can be a major factor for arsenic removal. Similar results were obtained by Yoon et al. [19] who investigated magnetite-graphene oxide and magnetite-reduced graphene oxide composite for $\mathrm{As}(\mathrm{III})$ and $\mathrm{As}(\mathrm{V})$ removal.

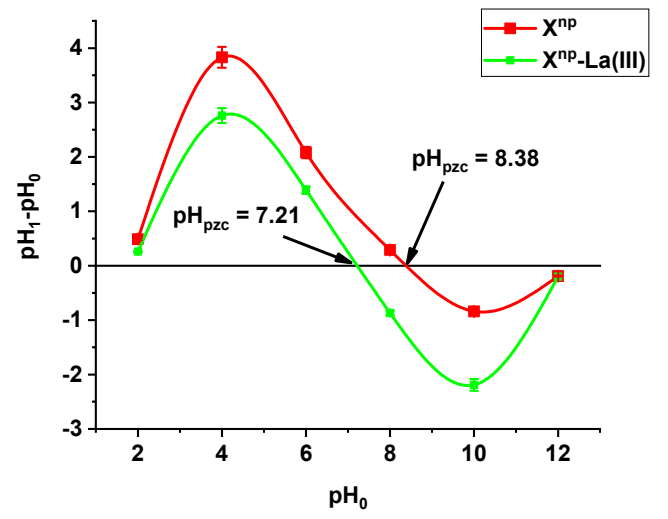

Figure 1. $\mathrm{pH}_{\mathrm{pzc}}$ measured by the drift method for $\mathrm{X}^{\mathrm{np}}$ before and after La(III) adsorption.

The SEM images of the raw and lanthanum-modified sorbent are presented in Figure 2.

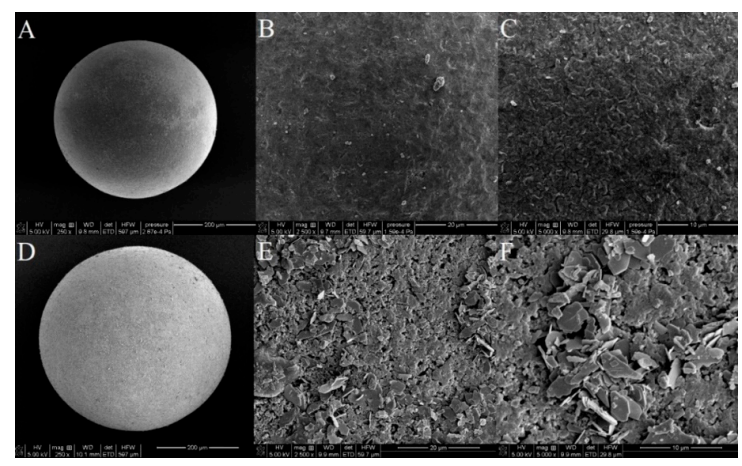

Figure 2. SEM images of $X^{\mathrm{np}}$ before $(\mathbf{A}-\mathrm{C})$ and after the modification with $\mathrm{La}(\mathrm{III})$ ions (D-F) at various magnifications (250×; 2500× and 5000×). 
The use of SEM scanning electron microscopy allowed a visual assessment of the surface structure of the tested sorbents. On the basis of the conducted tests, it can be assumed that after the sorption of lanthanum changes occur in the morphology of the sorbent surface, which becomes more heterogeneous. La (hydr)oxide nanoparticles and nanoflakes of several hundred nanometers spread over the surface. After the adsorption of $\mathrm{As}(\mathrm{V})$ process, morphology of $\mathrm{X}^{\mathrm{nP}}-\mathrm{La}(\mathrm{III})$ changes to be more "fluffy" similarly to the results presented in the paper by Vijaykumar et al. [21]. When the particle structure presents zero or low porosity, the specific surface area of the particle is a function of these attributes. Specific surface area, particle size as well as the presence of the functional groups are three of the most important parameters for sorptive materials of different types because they are related to the adsorption capacity and rate of the sorption processes. The smaller the size of the material, the higher is the surface area obtained. However, after aggregation of the particles during the La (hydr)oxide formation the surface area decreases.

The adsorption isotherms of $\mathrm{N}_{2}$ on the carbon adsorbers were used to determine surface characteristics, including the BET surface area and the micropore and mesopore volumes. In the case of the modified and unmodified sorbent, the $\mathrm{N}_{2}$ adsorption and desorption isotherm is type IV according to the International Union of Pure and Applied Chemistry (IUPAC) classification. For type IV there appears a hysteresis loop, which is associated with capillary condensation in the pores. The sorbent is characterized by the presence of micro- and mesopores. The initial part of the isotherm is associated with single and multilayer adsorption of $\mathrm{N}_{2}$ because it resembles the beginning of the type II isotherm. The adsorption hystereses (type IV and V) are classified and it is widely accepted that there is a correlation between the shape of the hysteresis loop and the texture (e.g., pore geometry, pore size distribution and connectivity) of a mesoporous material. An empirical classification of hysteresis loops was given by IUPAC, which is based on an earlier classification of hysteresis by de Boer. The tested materials demonstrate H3 hysteresis due to the slit-shaped pores [22]. The hysteresis loop shapes of $X^{\mathrm{np}}$ and $\mathrm{X}^{\mathrm{np}}-\mathrm{La}(\mathrm{III})$ are presented in Figure 3.

The specific surface area $\left(S_{B E T}\right)$ was evaluated based on the BET multilayer adsorption. The total pore volume $\left(V_{t}\right)$ was determined from the adsorbed nitrogen volume at $p / p_{0}=0.99$. The average pore diameter $\left(D_{p}\right)$ is estimated from the pore volume, assuming a cylindrical pore geometry and using the equation $4 V_{t} / S_{B E T}$. The mesopore distribution curve was obtained from the adsorption branch of the $\mathrm{N}_{2}$ isotherm by the Barett-Joyner-Halenda (BJH) method. The specific surface area of $\mathrm{X}^{\mathrm{np}}$ is equal to $55.27 \mathrm{~m}^{2} / \mathrm{g}$ and its total pore volume is $0.189 \mathrm{~cm}^{3} / \mathrm{g}$. Due to lanthanum(III) adsorption and the formation of nanoflakes, $X^{\mathrm{np}}$-La(III) demonstrates slightly lower values of the specific surface area and total pore volume, equal to $52.75 \mathrm{~m}^{2} / \mathrm{g}$ and $0.168 \mathrm{~cm}^{3} / \mathrm{g}$, respectively. There was also a slight difference in the average pore diameter of the unmodified sorbent $(13.70 \mathrm{~nm})$ and the modified one $(12.79 \mathrm{~nm})$. The data are presented in Table 2.

Table 2. Physical properties of $X^{n p}$ and $X^{n p}-\mathrm{La}(\mathrm{III})$.

\begin{tabular}{ccc}
\hline Ion Exchanger & $\mathbf{X}^{\mathbf{n p}}$ & $\mathbf{X}^{\mathbf{n p}}$-La(III) \\
\hline Specific surface area $\left(S_{B E T}\right)\left(\mathrm{m}^{2} / \mathrm{g}\right)$ & 55.27 & 52.75 \\
Total pore volume $\left(V_{t}\right)\left(\mathrm{cm}^{3} / \mathrm{g}\right)$ & 0.189 & 0.169 \\
Average pore diameter $\left(D_{p}\right)(\mathrm{nm})$ & 13.70 & 12.79 \\
\hline
\end{tabular}



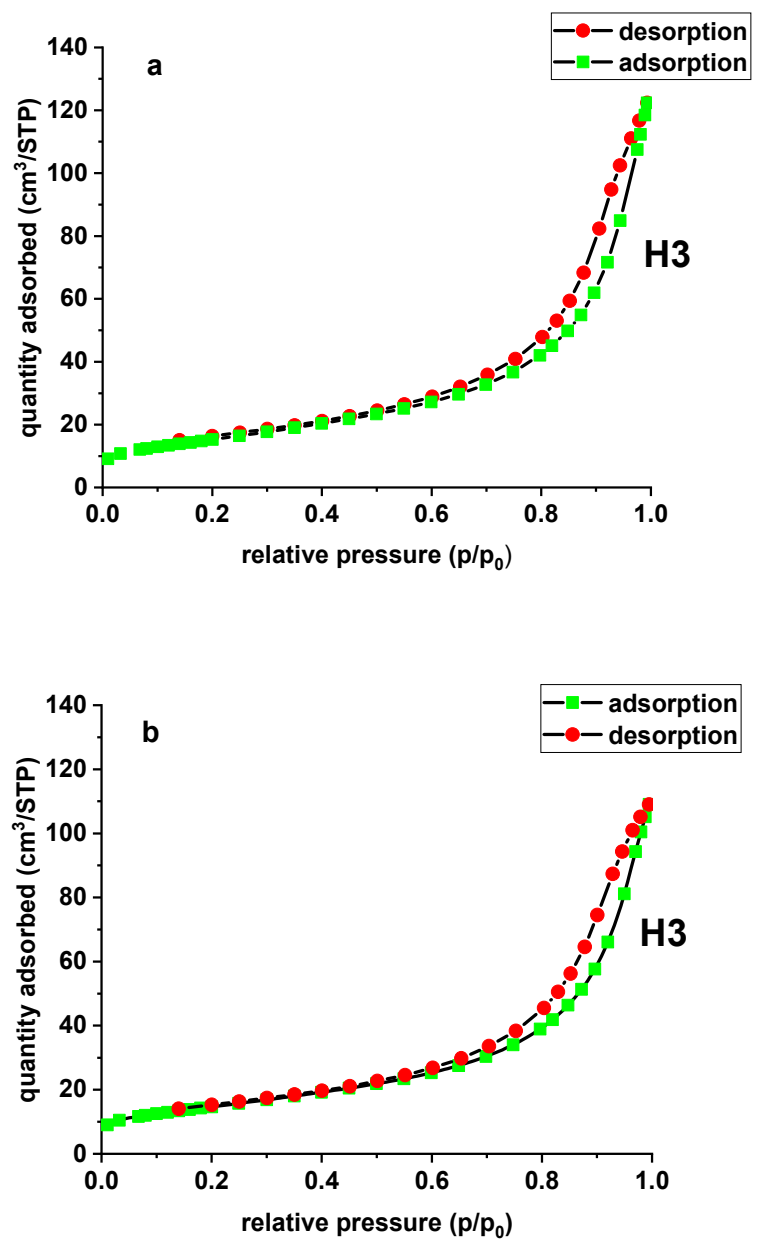

Figure 3. $\mathrm{N}_{2}$ adsorption/desorption isotherms of $X^{\mathrm{np}}$ (a) and $\mathrm{X}^{\mathrm{np}}$-La(III) (b).

FTIR spectra of $X^{\mathrm{np}}$ and $\mathrm{X}^{\mathrm{np}}$-La(III) were collected before and after sorption of $\mathrm{As}(\mathrm{V})$ ions (Figures 4 and 5). The bands at $3600-3200 \mathrm{~cm}^{-1}$ indicate an $\mathrm{O}-\mathrm{H}$ stretching group on the surface of iron oxide. The peak at $1638 \mathrm{~cm}^{-1}$ is observed to be the deformation vibration of water molecules physisorbed on the adsorbent. In comparison to the pure sorbent, the intensity of the above-mentioned peaks decreased after sorption of lanthanum and/or arsenic. Moreover, the absorption bands in the $1200-900 \mathrm{~cm}^{-1}$ region are attributed to the $\mathrm{S}=\mathrm{O}$ stretching vibrations in the $-\mathrm{SO}_{3}$ - groups, i.e., asymmetric and symmetric, as well as stretching of single $\mathrm{S}-\mathrm{OH}$. The increase of the peak intensity at $827 \mathrm{~cm}^{-1}$ was assigned to As-O-La bonding after the $\mathrm{As}(\mathrm{V})$ sorption onto $\mathrm{X}^{\mathrm{np}}$-La(III). In their paper, Jais et al. demonstrated two peaks at 808 and $839 \mathrm{~cm}^{-1}$ derived from the As-O-La group [23]. These can indicate that arsenate(V) ions were primarily bound as a surface complex. Additionally, based on paper [24], it was found that with the increasing sorption time, the intensity of the band corresponding to the vibrations of As-O bond was progressively increased which is correlated with the fact that the amount of adsorbed $\mathrm{As}(\mathrm{V})$ also changed over the $\mathrm{pH}$ values. What is more, the peak position is shifted from $839 \mathrm{~cm}^{-1}$ to $819 \mathrm{~cm}^{-1}$ with the $\mathrm{pH}$ change from 5 to 9. In the case of the sorption of $\mathrm{As}(\mathrm{V})$ on silica derived sorbent [11] the peak around $960 \mathrm{~cm}^{-1}$ is connected with the La(III) modification. The Author found that in the case of the increase in lanthanum impregnation degree the absorbance intensities at $960 \mathrm{~cm}^{-1}$ decreased due to formation of $\mathrm{Si}-\mathrm{O}-\mathrm{La}$ bonds. It can be suggested that the monolayer phase of lanthanum oxide may be dominant at below lower lanthanum impregnation, while the multilayer phase of lanthanum oxide may be dominant at the higher lanthanum impregnation. However, the peak at $790 \mathrm{~cm}^{-1}$ is connected with the PS-DVB ion exchanger structure. 


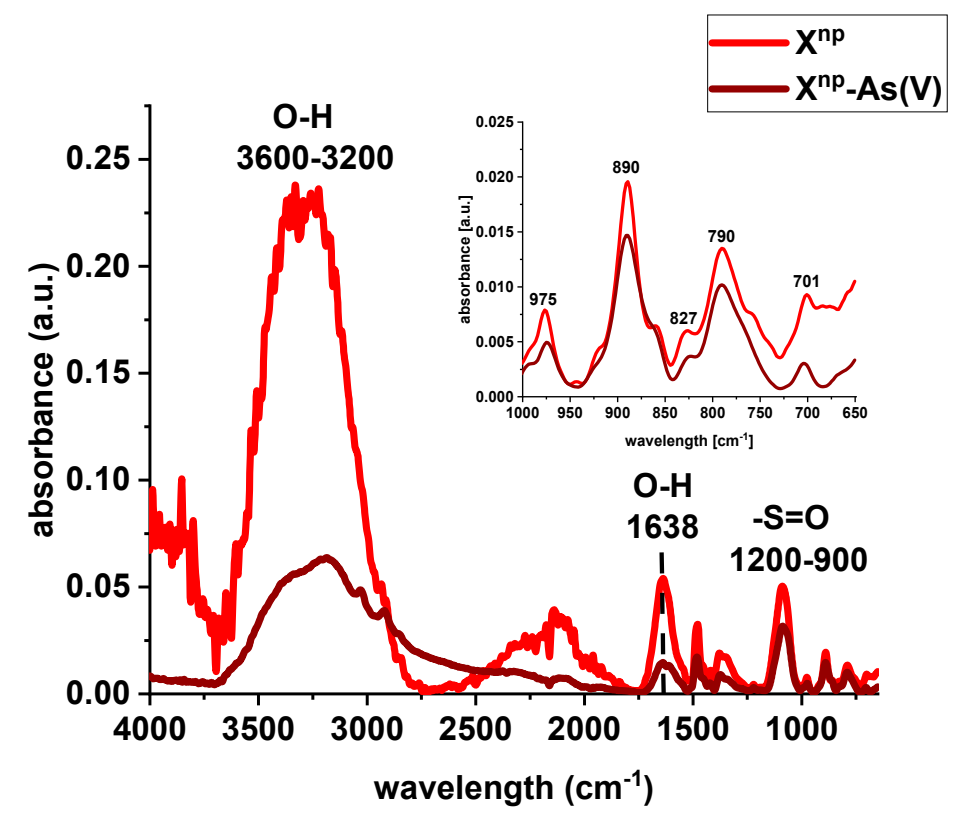

Figure 4. FTIR spectra of $\mathrm{X}^{\mathrm{np}}$ before and after sorption of $\mathrm{As}(\mathrm{V})$ ions.

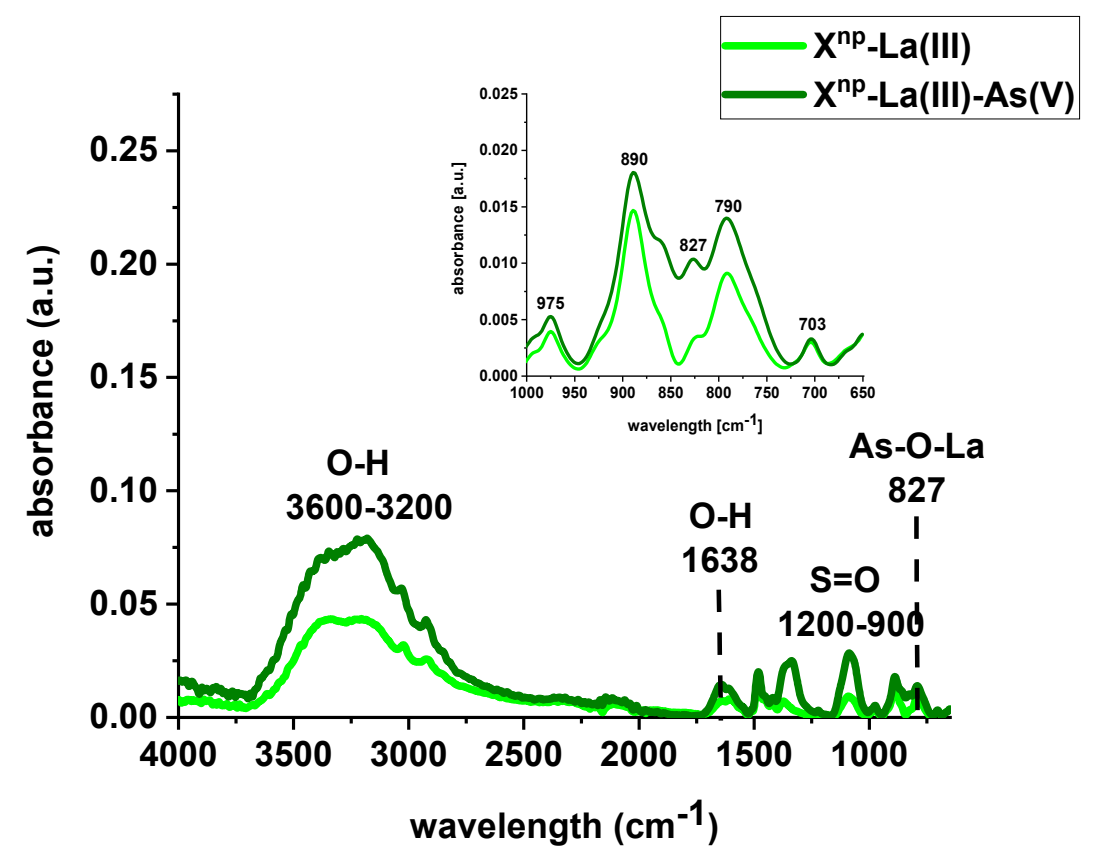

Figure 5. FTIR spectra of $\mathrm{X}^{\mathrm{np}}$-La(III) before and after sorption of $\mathrm{As}(\mathrm{V})$ ions.

\subsection{Sorbent Modification}

Studying the effect of $\mathrm{pH}$ on $\mathrm{La}(\mathrm{III})$ sorption on $\mathrm{X}^{\mathrm{np}}$, it was found that the maximum sorption capacity was obtained at $\mathrm{pH} 4$ (Figure 6). At $\mathrm{pH}>6$, the precipitation of $\mathrm{La}(\mathrm{OH})_{3}$ occurred and therefore lanthanum(III) adsorption became impossible to proceed. 


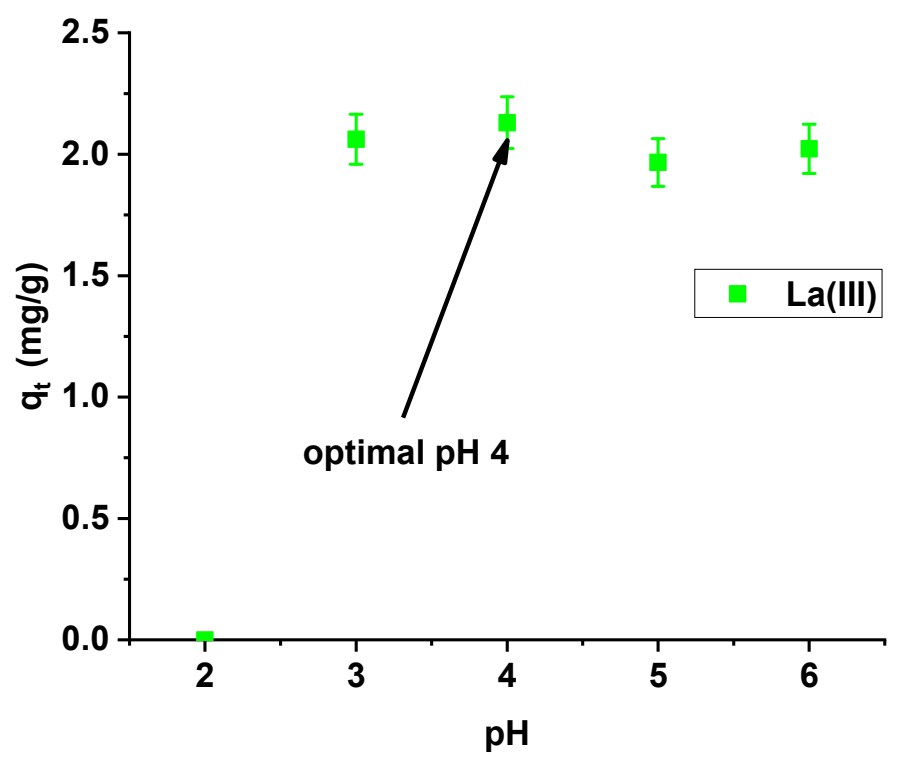

Figure 6. Effect of $\mathrm{pH}$ on lanthanum(III) adsorption on $\mathrm{X}^{\mathrm{np}}\left(\mathrm{c}_{0}=10 \mathrm{mg} / \mathrm{dm}^{3} ; \mathrm{m}=0.1 \mathrm{~g} ; \mathrm{t}=24 \mathrm{~h}\right)$.

Sorption capacities at the $\mathrm{pH}$ range from 3 to 6 are similar, but slightly higher at $\mathrm{pH} 4$, so this value was selected for further studies.

Kinetic studies show that the La(III) adsorption processes are quite fast. It is observed that sorption efficiency is greater for solutions with lower initial concentrations (Figure 7).

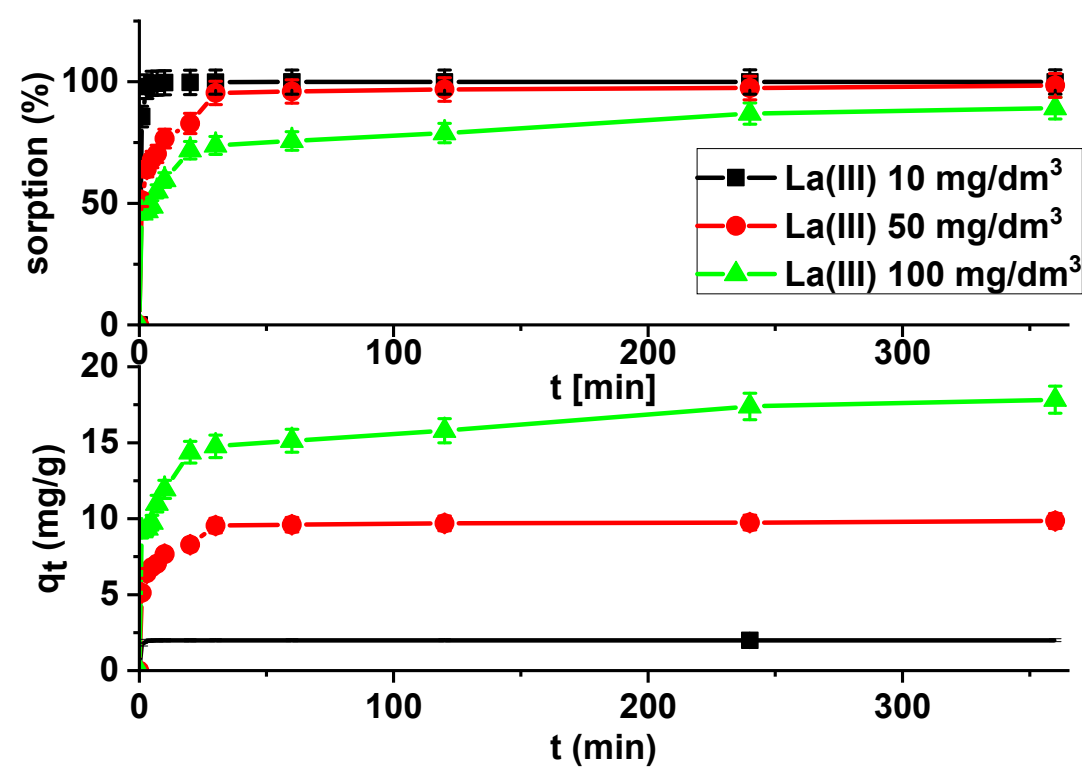

Figure 7. Lanthanum(III) sorption efficiency and sorption capacities as a function of time on $\mathrm{X}^{\mathrm{np}}$ $\left(c_{0}=10,50\right.$ and $100 \mathrm{mg} / \mathrm{dm}^{3}, \mathrm{pH}=4$, shaking speed $180 \mathrm{rpm}$, temperature $295 \mathrm{~K}$ ).

It was found that the linear regression coefficient based on the pseudo-second order (PSO) model $\left(R^{2}>0.99\right)$ gave the best fitting (Table 3, Figure 8). Based on the PSO model, the calculated adsorption capacities $(1.99,9.84,17.82)$ were nearly the same as the experimental ones. The adsorption rate constants decreased with the increase in $\mathrm{La}(\mathrm{III})$ initial concentration. 
Table 3. Kinetic parameters of lanthanum(III) adsorption on $\mathrm{X}^{\mathrm{np}}$.

\begin{tabular}{|c|c|c|c|}
\hline \multirow{2}{*}{ Kinetic Parameters } & \multicolumn{3}{|c|}{$X^{n p}-\mathrm{La}(\mathrm{III})$} \\
\hline & $10\left(\mathrm{mg} / \mathrm{dm}^{3}\right)$ & $50\left(\mathrm{mg} / \mathrm{dm}^{3}\right)$ & $100\left(\mathrm{mg} / \mathrm{dm}^{3}\right)$ \\
\hline \multicolumn{4}{|c|}{ PFO } \\
\hline$q_{1, \text { cal }}$ & 0.01 & 2.06 & 6.71 \\
\hline$k_{1}$ & 0.025 & 0.016 & 0.011 \\
\hline$R^{2}$ & 0.6537 & 0.6786 & 0.9105 \\
\hline \multicolumn{4}{|c|}{ PSO } \\
\hline$q_{2, c a l}$ & 2.00 & 9.89 & 17.87 \\
\hline$k_{2}$ & 8.968 & 0.045 & 0.010 \\
\hline$h$ & 35.843 & 4.406 & 3.131 \\
\hline$R^{2}$ & 1.0000 & 0.9999 & 0.9986 \\
\hline
\end{tabular}

Where: $q_{1, \text { cal }}$ and $q_{2, \text { cal }}$-the calculated amount of arsenic adsorbed at equilibrium for the PFO and PSO models; $k_{1}$ and $k_{2}$ are the reaction rate constants of the pseudo-first order $(1 / \mathrm{min})$ and pseudo-second order $(\mathrm{g} / \mathrm{mg} \mathrm{min})$, $R^{2}$ - the correlation coefficient; $h$ - the initial rate of adsorption for the PSO model ( $\mathrm{mg} / \mathrm{g} \mathrm{min}$ ).

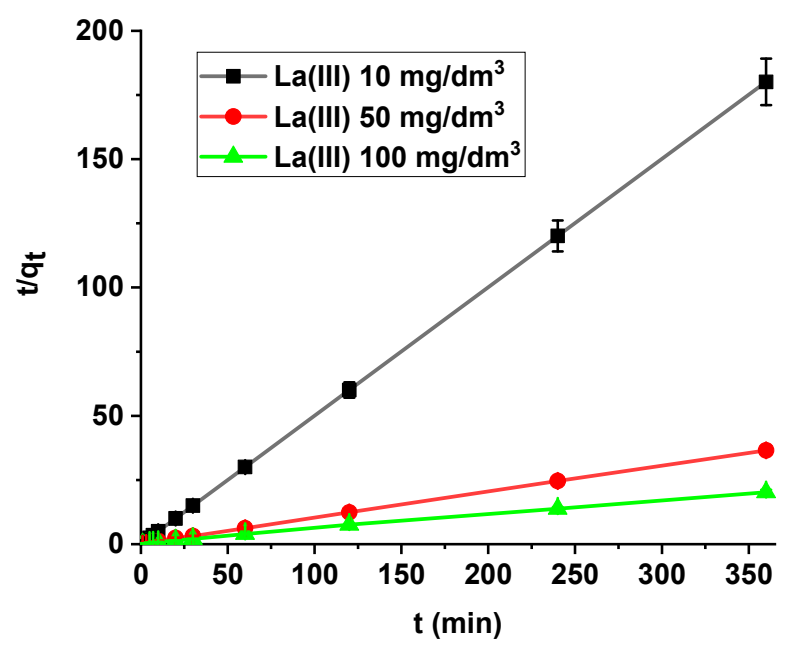

Figure 8. PSO plots of lanthanum(III) adsorption on $\mathrm{X}^{\mathrm{np}}\left(\mathrm{c}_{0}=10,50,100 \mathrm{mg} / \mathrm{dm}^{3}, \mathrm{pH}=4\right.$, shaking speed $180 \mathrm{rpm}$, temperature $295 \mathrm{~K})$.

The isotherm data were analysed using the Langmuir and Freundlich models (Figure 9).

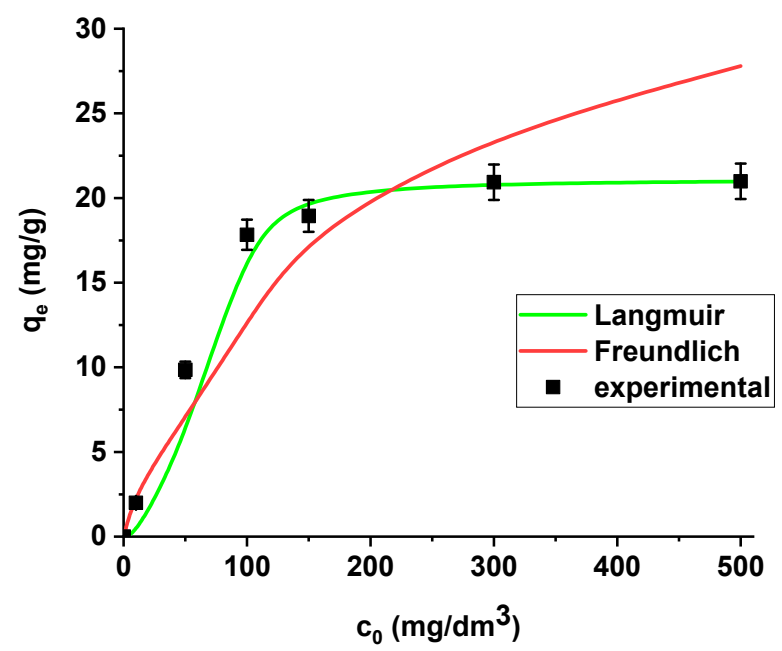

Figure 9. The Langmuir and Freundlich sorption isotherms of $\mathrm{La}(\mathrm{III})$ on $\mathrm{X}^{\mathrm{np}}$ (pH 4, shaking speed $180 \mathrm{rpm}$, temperature $295 \mathrm{~K})$. 
$\mathrm{La}(\mathrm{III})$ adsorption was described better by the Langmuir model $\left(R^{2}=0.9998\right)$ than the Freundlich model $\left(R^{2}=0.8996\right)$. $X^{\mathrm{np}}$ demonstrates the maximum sorption capacity towards lanthanum(III) equal to $21.08 \mathrm{mg} / \mathrm{g}$. It is worth mentioning that the coefficient $R_{L}$ lies in the range $0-1(0.171)$, which indicates that the process is favourable.

\subsection{Influence of $p H$ on $A s(V)$ Adsorption on $X^{n p}-L a(I I I)$}

Arsenic is present in compounds at various oxidation states, but the most common ones are $-3,0,+3$, and +5 [25]. Arsenic $(\mathrm{V})$ is more readily adsorbed on solid surfaces than arsenic(III), so in order to remove arsenic effectively, all forms of arsenic should be oxidized to the +5 oxidation state. Moreover, inorganic arsenic compounds are more toxic than organic ones, and as for the oxidation state, arsenic(III) is usually more toxic than arsenic(V). The most common inorganic forms of arsenic are arsenic(III) and arsenic $(\mathrm{V})$, the amount of which depends on the $\mathrm{pH}$ and redox potential. At $\mathrm{pH} 3-9$, arsenic(III) dominates as undissociated $\mathrm{H}_{3} \mathrm{AsO}_{3}$, while arsenic(V) exists as the anions $\mathrm{HAsO}_{4}{ }^{2-}$ and $\mathrm{H}_{2} \mathrm{AsO}_{4}{ }^{-}\left(\mathrm{pK}_{1}=2.2, \mathrm{pK}_{2}=7.1, \mathrm{pK}_{3}=11.5\right)$ [26]. At $\mathrm{pH} 6$, arsenic(V) exists as the anions $\mathrm{HAsO}_{4}{ }^{2-}$ and $\mathrm{H}_{2} \mathrm{AsO}_{4}^{-}$.

On the basis of the presented results of dependence of sorption capacities of the tested hybrid material on the initial $\mathrm{pH}$ of the arsenic $(\mathrm{V})$ solution, the sorption capacities of $\mathrm{X}^{\mathrm{np}}$-La(III) were observed to be almost equal. The highest efficiency of $\operatorname{arsenic}(\mathrm{V})$ sorption was achieved at $\mathrm{pH} 6$ (Figure 10). At $\mathrm{pH} 6$, arsenic $(\mathrm{V})$ exists as the anions $\mathrm{HAsO}_{4}{ }^{-}$and $\mathrm{H}_{2} \mathrm{AsO}_{4}{ }^{-}$. As follows from the speciation distribution the ratio of $\mathrm{HAsO}_{4}{ }^{2-}$ and $\mathrm{H}_{2} \mathrm{AsO}_{4}{ }^{-}$are about $10 \%$ : 90\% [27]. Consequently, they can be more readily adsorbed on an electrically charged surface. Additionally, as follows form the paper by Sarkar et al. [28] it is worth noting that the chronic toxicity caused by the presence of low concentration of arsenic (well below $1 \mathrm{mg} / \mathrm{L}$ ) is not influenced by the relative distribution of $\mathrm{As}(\mathrm{III})$ and $\mathrm{As}(\mathrm{V})$. At such low concentration, $\mathrm{As}(\mathrm{V})$ gets instantaneously converted to As(III). That is why the World Health Organization (WHO), the United States Environmental Protection Agency (USEPA), and the European Union (EU), specify only the total amount of arsenic for the maximum contamination level (MCL) in drinking water.

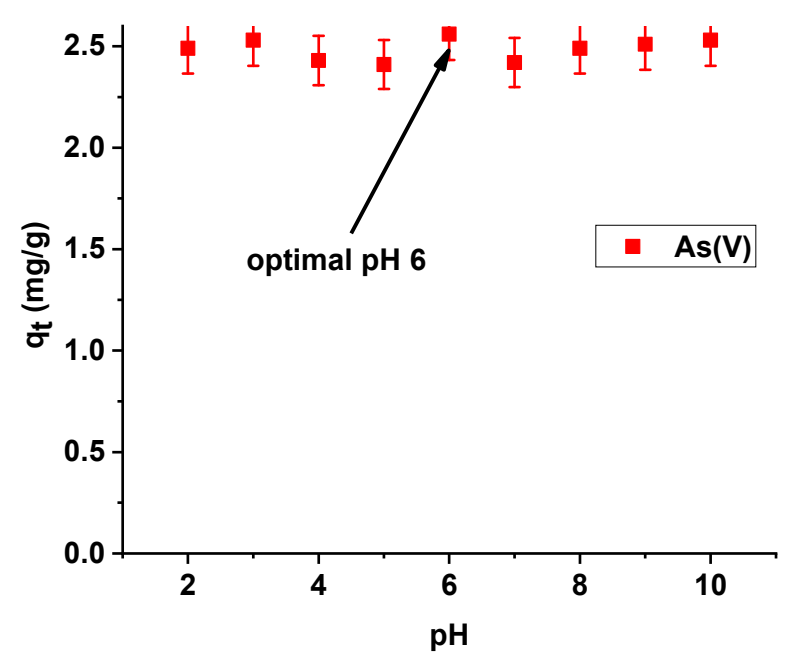

Figure 10. Effect of $\mathrm{pH}$ on adsorption of arsenic(V) on $\mathrm{X}^{\mathrm{np}}-\mathrm{La}(\mathrm{III})\left(\mathrm{c}_{0}=10 \mathrm{mg} / \mathrm{L} ; \mathrm{m}=0.1 \mathrm{~g} ; \mathrm{t}=24 \mathrm{~h}\right.$, $\mathrm{T}=295 \mathrm{~K}$, shaking speed $180 \mathrm{rpm}$ ).

Thus, the $\mathrm{pH}$ value of 6 , which is slightly lower than the $\mathrm{pH}$ of municipal water, was selected for further studies for both $\mathrm{X}^{\mathrm{np}}$ and $\mathrm{X}^{\mathrm{nP}}$-La(III) to ensure uniform conditions of arsenic (V) ions. In addition, a $\mathrm{pH}$ of 6 is a value below the $\mathrm{pH}_{\mathrm{pzc}}$ of $\mathrm{X}^{\mathrm{np}}$ and $\mathrm{X}^{\mathrm{np}}-\mathrm{La}(\mathrm{III})$. The positively charged surfaces of the modified and unmodified sorbent should attract hydrogen arsenate $(\mathrm{V})$ and dihydrogen arsenate $(\mathrm{V})$ anions. 


\subsection{Kinetic Studies of $A s(V)$ on $X^{n p}-L a(I I I)$}

In the case of a static method, for all practical purposes the choice of experimental variables usually narrows down to two: the concentration and amount of sorbent. In the presented results, for comparison the adsorption studies were carried out for $\mathrm{X}^{\mathrm{np}}$ before and after modification. Figures 11 and 12 show that all the presented adsorption processes are quite fast. It is observed that sorption efficiency (\%) is greater for the solutions with lower initial concentrations. For example, in the case of $\mathrm{X}^{\mathrm{np}}$ at the highest adsorption percentage the concentration of arsenic(V) was reduced from $25 \mathrm{mg} / \mathrm{dm}^{3}$ to $0.94 \mathrm{mg} / \mathrm{dm}^{3}$. Interestingly, arsenate $(\mathrm{V})$ ions were completely removed from the 25 and $50 \mathrm{mg} / \mathrm{dm}^{3}$ solutions in the case of $\mathrm{X}^{\mathrm{np}}$-La(III) (100\% sorption efficiency). The ability to remove arsenic completely at relatively low initial concentrations is very important and shows successful modification. Li et al. examined hybrid Ce-Ti sorbent in terms of arsenic removal [29]. The authors claimed that in industrial drinking water treatment, the arsenic $(V)$ concentration usually does not exceed $0.1 \mathrm{mg} / \mathrm{dm}^{3}$ and the final arsenic concentration in wastewater must be lower than the generally accepted limit of $10 \mu \mathrm{g} / \mathrm{dm}^{3}$ and therefore the sorption ability to adsorb at a low initial arsenic(V) concentration is more important than the maximum sorption capacity obtained experimentally at high arsenic(V) concentration. To predict the optimal conditions of adsorbate removal both isotherm adsorption and intraparticle kinetic parameters should be determined under different system conditions because they are dependent, among others, on the concentration, temperature and interactions between the adsorbent and the adsorbate. If the adsorbent possesses particular functional groups and active centres to adsorb the adsorbate, its effect should be evaluated from the experimental data.

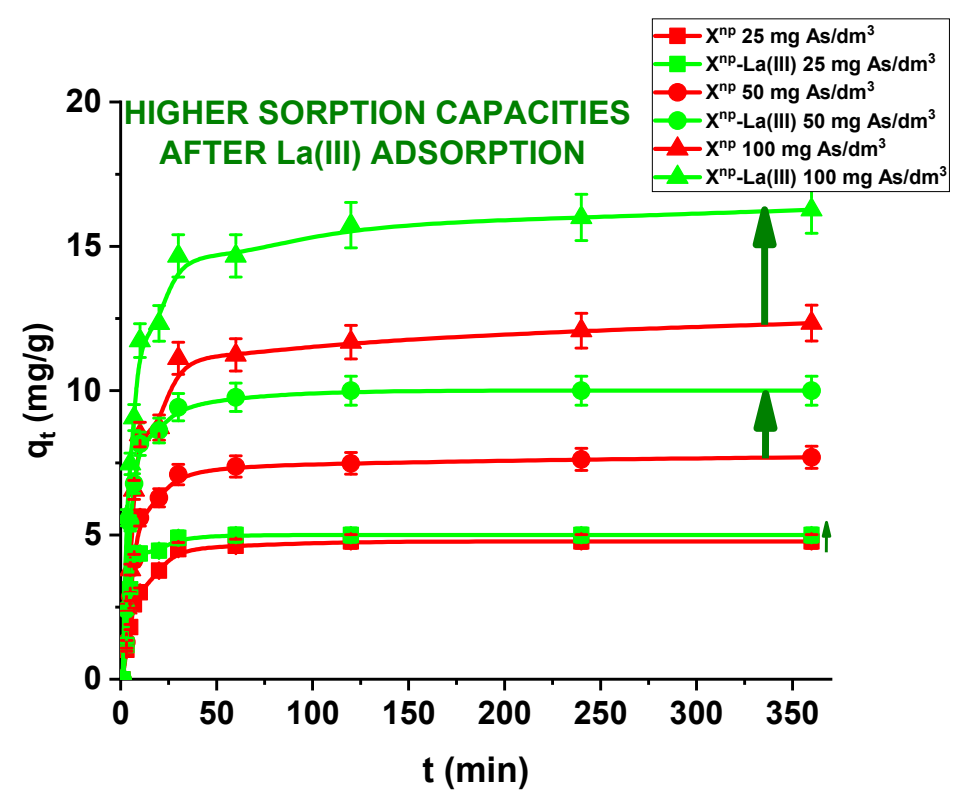

Figure 11. Sorption of arsenic(V) on $X^{n p}$ and $X^{n p}-\mathrm{La}(I I I)$ as a function of time $\left(c_{0}=25,50\right.$ and $100 \mathrm{mg} / \mathrm{dm}^{3}, \mathrm{pH}=6$, shaking speed $180 \mathrm{rpm}$, temperature $\left.295 \mathrm{~K}\right)$. 


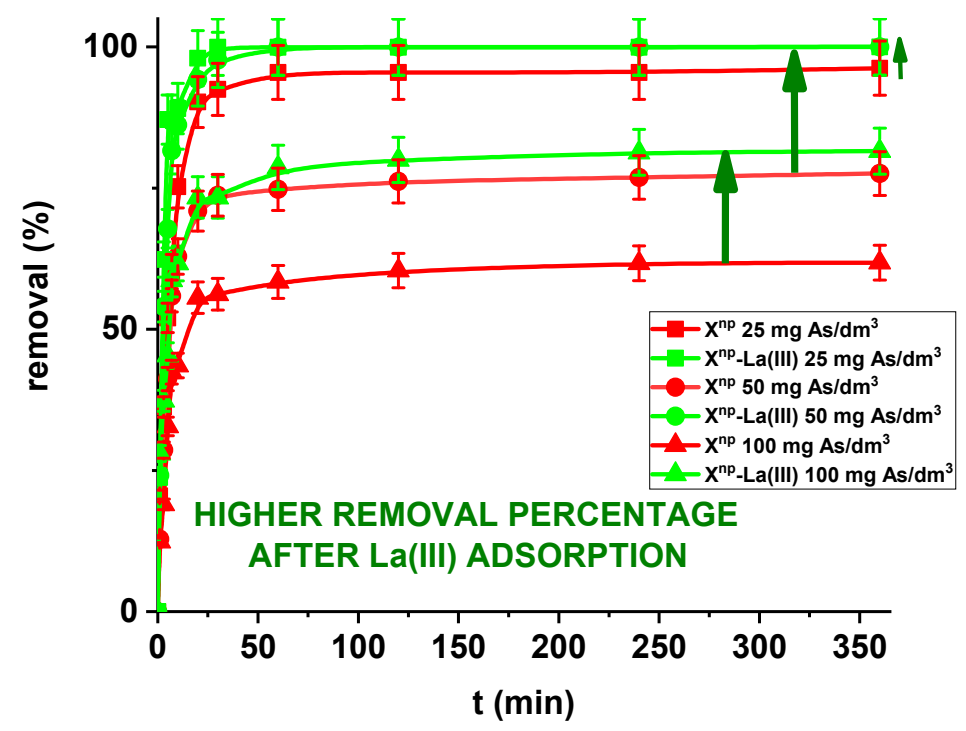

Figure 12. Arsenic(V) sorption efficiency for $X^{n p}$ and $X^{n p}-\mathrm{La}(\mathrm{III})\left(\mathrm{c}_{0}=25,50\right.$ and $100 \mathrm{mg} / \mathrm{dm}^{3}, \mathrm{pH}=6$, shaking speed $180 \mathrm{rpm}$, temperature $295 \mathrm{~K}$ ).

Moreover, in our studies arsenic(V) ions sorption increases very sharply within the first $15 \mathrm{~min}$ of the phase contact time and the equilibrium appears to be reached after $120 \mathrm{~min}$ with the adsorption capacities equal to $4.81,7.76$, and $12.36 \mathrm{mg} / \mathrm{g}$ for $\mathrm{X}^{\mathrm{np}}$ as well as $5.00,10.00$ and $16.31 \mathrm{mg} / \mathrm{g}$ for $\mathrm{X}^{\mathrm{np}}$-La(III) at initial concentrations of 25,50 and $100 \mathrm{mg} / \mathrm{dm}^{3}$, respectively. These results demonstrate that the 120-min phase contact time selected for adsorption studies is adequate for adsorption on both sorbents. The adsorption is the fastest at the beginning of the process at short time intervals and then gradually declines throughout the studied period. This indicates that as the adsorption sites on $X^{n p}$ and $X^{\text {np }}$-La(III) surface were occupied, the rate of adsorption decreased.

Comparing the kinetic studies of $\operatorname{arsenic}(\mathrm{V})$, it was found that the linear regression coefficient based on the pseudo-second order (PSO) model $\left(R^{2}>0.99\right)$ gave the best fitting (Tables 4 and 5 , Figure 13) for both $\mathrm{X}^{\mathrm{np}}$ and $\mathrm{X}^{\mathrm{np}}-\mathrm{La}(\mathrm{III})$. The $\mathrm{As}(\mathrm{V})$ adsorption rate constants determined using the PSO model are 0.030, 0.018 and 0.009 1/min, while the adsorption capacities are 3.14, 5.07, and 8.64 $\mathrm{mg} / \mathrm{g}$ for $\mathrm{X}^{\mathrm{np}}$. For $\mathrm{X}^{\mathrm{np}}$-La(III), they are higher and equal to $0.178,0.057,0.0201 / \mathrm{min}$, whereas the adsorption capacities are $5.02,10.07$, and $16.46 \mathrm{mg} / \mathrm{g}$. It is worth mentioning that the $q_{e, \exp }$ values are well comparable with these calculated $q_{e, c a l}$ (Tables 4 and 5). What is more, an increase in the initial arsenic $(\mathrm{V})$ concentration leads to an increase in the adsorption capacity.

Table 4. Kinetic parameters of arsenic(V) adsorption on $X^{n p}$.

\begin{tabular}{|c|c|c|c|}
\hline \multirow{2}{*}{ Kinetic Parameters } & \multicolumn{3}{|c|}{$\mathrm{X}^{\mathrm{np}}-\mathrm{As}(\mathrm{V})$} \\
\hline & $25\left(\mathrm{mg} / \mathrm{dm}^{3}\right)$ & $50\left(\mathrm{mg} / \mathrm{dm}^{3}\right)$ & $100\left(\mathrm{mg} / \mathrm{dm}^{3}\right)$ \\
\hline \multicolumn{4}{|c|}{ PFO } \\
\hline$q_{1, \mathrm{cal}}$ & 0.83 & 1.70 & 4.55 \\
\hline$k_{1}$ & 0.032 & 0.031 & 0.032 \\
\hline$R^{2}$ & 0.4355 & 0.5807 & 0.7847 \\
\hline \multicolumn{4}{|c|}{ PSO } \\
\hline$q_{2, c a l}$ & 3.14 & 5.07 & 8.64 \\
\hline$k_{2}$ & 0.030 & 0.018 & 0.009 \\
\hline$h$ & 0.292 & 0.460 & 0.702 \\
\hline$R^{2}$ & 0.9999 & 0.9999 & 0.9999 \\
\hline
\end{tabular}


Table 5. Kinetic parameters of arsenic(V) adsorption on $\mathrm{X}^{\mathrm{np}}$-La(III).

\begin{tabular}{|c|c|c|c|}
\hline \multirow{2}{*}{ Kinetic Parameters } & \multicolumn{3}{|c|}{$X^{n p}-A s(V)-L a(I I I)$} \\
\hline & $25\left(\mathrm{mg} / \mathrm{dm}^{3}\right)$ & $50\left(\mathrm{mg} / \mathrm{dm}^{3}\right)$ & $100\left(\mathrm{mg} / \mathrm{dm}^{3}\right)$ \\
\hline \multicolumn{4}{|c|}{ PFO } \\
\hline$q_{1, \mathrm{cal}}$ & 0.29 & 1.34 & 5.09 \\
\hline$k_{1}$ & 0.029 & 0.036 & 0.021 \\
\hline$R^{2}$ & 0.4854 & 0.6614 & 0.8920 \\
\hline \multicolumn{4}{|c|}{ PSO } \\
\hline$q_{2, c a l}$ & 5.02 & 10.07 & 16.46 \\
\hline$k_{2}$ & 0.178 & 0.057 & 0.020 \\
\hline$h$ & 4.488 & 5.825 & 5.306 \\
\hline$R^{2}$ & 0.9999 & 0.9999 & 1.0000 \\
\hline
\end{tabular}

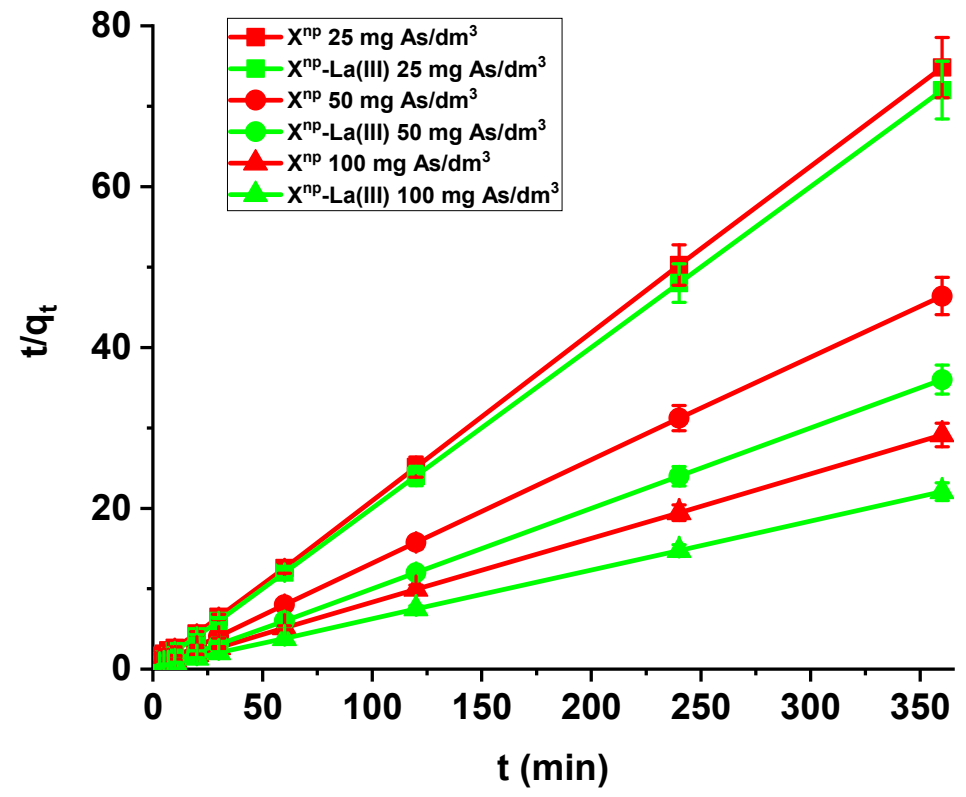

Figure 13. PSO plots of arsenic(V) adsorption on $X^{n p}$ (red) and $X^{n p}$-La(III) (green) $\left(c_{0}=25,50\right.$, $100 \mathrm{mg} / \mathrm{dm}^{3}$, pH 6, shaking speed $180 \mathrm{rpm}$, temperature $295 \mathrm{~K}$ ).

It can be noticed that the adsorption involves bulk phase transport of the metal ions to the external surface of $X^{n p}$, transport across the boundary layer (external mass transfer), transport through/within $\mathrm{X}^{\mathrm{np}}$ by surface diffusion and/or pore diffusion (intraparticle diffusion), and adsorption on the adsorbent surface. The last one can be affected by the stirring rate, volume, and initial concentration of the solution.

\subsection{Equilibrium Adsorption of $A s(V)$ on $X^{n p}$-La(III)}

The isotherm data were analysed using the Langmuir and Freundlich models to provide an insight into the interactions between the adsorbent and the adsorbate. Sorption equilibrium is usually described by an isotherm equation whose parameters express the affinity and surface properties of the sorbent at a fixed temperature and $\mathrm{pH}$. To optimise an adsorption system, it is important to establish the most appropriate correlations for the equilibrium. Therefore, the isotherm data were analysed using the Langmuir and Freundlich isotherm models. Therefore, the isotherm data were analysed using the Langmuir and Freundlich isotherm models. The correlation parameter $\left(R^{2}\right)$ and the corresponding average relative errors were calculated according to the following equation:

$$
\Delta q(\%)=\sum_{i=1}^{N}\left|\frac{q_{\exp }-q_{0}}{q_{\exp }}\right| \times \frac{100}{N}
$$


where: $q_{\exp }$ 一the experimental amount of arsenic adsorbed at equilib $\neg$ rium $(\mathrm{mg} / \mathrm{g}) ; q_{0}$ 一the calculated amount of arsenic adsorbed at equilibrium and $\mathrm{N}$-the number of the experimental data.

The results are summarized in Table 6. The regression coefficients $\left(R^{2}\right)$ are higher for the Langmuir model in both cases, i.e., the sorption of $\mathrm{As}(\mathrm{V})$ on the unmodified and modified sorbent. What is more, the average relative errors are smaller for the Langmuir equation in both cases. The high correlation coefficients and relatively small errors suggested that the Langmuir model provides good fit of the experimental adsorption data and can be applied for description of the sorption process. The sorption capacity of $X^{n p}$ and $X^{n p}-\mathrm{La}(\mathrm{III})$ increased with the increase in arsenic concentration in the solution. Based on the Langmuir model, the maximum sorption capacities towards arsenic $(\mathrm{V})$ were determined as $22.37 \mathrm{mg} / \mathrm{g}$ and $61.97 \mathrm{mg} / \mathrm{g}$ on $\mathrm{X}^{\mathrm{np}}$ and $\mathrm{X}^{\mathrm{np}}$-La(III), respectively. It is worth noting that the maximum sorption capacity of the modified sorbent is almost 3 times greater than the unmodified one. For the Freundlich model, the $K_{F}$ values related to arsenic $(V)$ adsorption on the unmodified and modified ion exchanger are equal to 4.64 and 14.49 , respectively (Table 6). The parameters $R_{L}\left(0<R_{L}<1\right)$ for adsorption of arsenic $(\mathrm{V})$ on both sorbents indicate that the process is favourable. The Langmuir and Freundlich sorption isotherms of $\mathrm{As}(\mathrm{V})$ on $\mathrm{X}^{\mathrm{np}}$ and $\mathrm{X}^{\mathrm{np}}-\mathrm{La}(\mathrm{III})$ are presented in Figures 14 and 15.

Table 6. The Langmuir and Freundlich parameters for adsorption of arsenic(V) on $X^{n p}$ and $X^{n p}$-La(III) (pH 6, shaking speed $180 \mathrm{rpm}$, temperature $295 \mathrm{~K}$ ).

\begin{tabular}{ccc}
\hline Isotherm Parameters & $\mathbf{X}^{\mathrm{np}}-\mathbf{A s}(\mathbf{V})$ & $\mathbf{X}^{\mathrm{np}}$-La(III)-As(V) \\
\hline & Langmuir Model & \\
\hline$q_{0}$ & 22.37 & 61.97 \\
$\boldsymbol{K}_{\boldsymbol{L}}$ & 0.047 & 0.017 \\
$\boldsymbol{R}_{\boldsymbol{L}}$ & 0.462 & 0.696 \\
$\boldsymbol{R}^{2}$ & 0.9931 & 0.9637 \\
error $(\%)$ & 5.47 & 6.54 \\
\hline & Freundlich Model & \\
$\boldsymbol{K}_{\boldsymbol{F}}$ & 4.64 & 14.49 \\
$\boldsymbol{n}$ & 3.775 & 5.589 \\
$\boldsymbol{R}^{\mathbf{2}}$ & 0.9790 & 0.8611 \\
error $(\%)$ & 6.50 & 18.28 \\
\hline
\end{tabular}

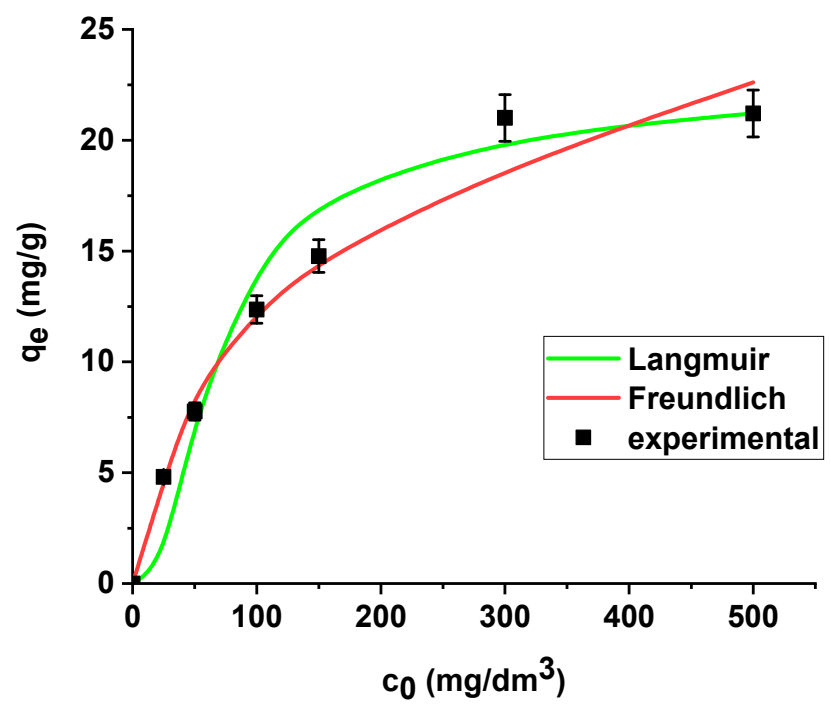

Figure 14. The Langmuir and Freundlich sorption isotherms of $\mathrm{As}(\mathrm{V})$ on $\mathrm{X}^{\mathrm{np}}$ (pH 6, shaking speed $180 \mathrm{rpm}$, temperature $295 \mathrm{~K})$. 


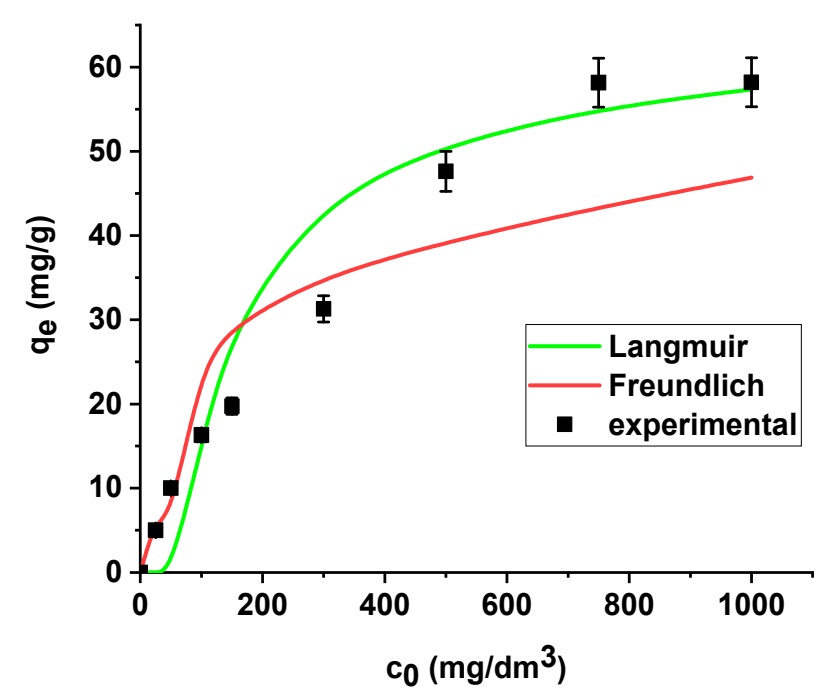

Figure 15. The Langmuir and Freundlich sorption isotherms of $\mathrm{As}(\mathrm{V})$ on $\mathrm{X}^{\mathrm{np}}$-La(III) (pH 6, shaking speed $180 \mathrm{rpm}$, temperature $295 \mathrm{~K})$.

In the case of commercial hybrid ion exchangers based on nanosized iron oxides, their quality depends on the quantity, structure, crystallinity and degree of dispersion of the iron oxides introduced, the physical form of the base polymer, the type of functional groups involved in the preparation of hybrid polymers as well as their influence on the process of adsorption [7]. The process of dispersing of iron oxide can be applied to different types of polymers such as those containing sulfonic, diphosphonic/sulfonic/carboxylic, bispicolylamine or quaternary ammonium as well as iminodiacetic functional groups:

$$
\mathrm{R}-\mathrm{SO}_{3} \mathrm{H}+\mathrm{Fe}^{2+} \rightleftharpoons \mathrm{R}-\left(\mathrm{SO}_{3}\right)_{2} \mathrm{Fe}+2 \mathrm{H}^{+}
$$

and slow oxidation of $\mathrm{Fe}(\mathrm{II})$ into $\mathrm{Fe}_{3} \mathrm{O}_{4}$ at alkaline $\mathrm{pH}$, i.e.,

$$
\mathrm{R}-\left(\mathrm{SO}_{3}\right)_{2} \mathrm{Fe}+2 \mathrm{Na}^{+} \rightleftharpoons 2 \mathrm{R}-\mathrm{SO}_{3} \mathrm{Na}+\mathrm{Fe}^{2+}
$$

as well as

$$
\begin{gathered}
3 \mathrm{Fe}^{2+}+0.5 \mathrm{O}_{2}+3 \mathrm{H}_{2} \mathrm{O} \rightleftharpoons \mathrm{Fe}_{3} \mathrm{O}_{4} \downarrow+6 \mathrm{H}^{+} \text {and } \mathrm{Fe}^{2+}+2 \mathrm{OH}^{-} \rightleftharpoons \mathrm{Fe}(\mathrm{OH})_{2} \downarrow \\
\text { or } \mathrm{Fe}(\mathrm{OH})_{2} \downarrow+0.5 \mathrm{O}_{2} \rightleftharpoons \mathrm{Fe}_{3} \mathrm{O}_{4} \downarrow+3 \mathrm{H}_{2} \mathrm{O}
\end{gathered}
$$

where: $\mathrm{R}$ is the resin matrix.

The magnetic properties of these sorbents are greatly influenced by the kind of functional groups. They were found to change in the following order: sulfonic $>$ diphosphonic/sulfonic/carboxylic $>$ bispicolylamine > iminodiacetic. However, in the case of introducing the hydrated Fe(III) oxide (HFO), to obtain hybrid ion exchangers (HIXs) the first step of preparation includes loading of Fe(III) onto the functional groups of the ion exchanger (for example sulfonic one), then desorption of Fe(III) and simultaneous precipitation of Fe(III) hydroxides within the gel and pore phase of the exchanger by passage of a solution containing both $\mathrm{NaCl}$ and $\mathrm{NaOH}$ :

$$
\begin{gathered}
\mathrm{R}-\mathrm{SO}_{3} \mathrm{H}+\mathrm{Fe}^{3+} \rightleftharpoons \mathrm{R}-\left(\mathrm{SO}_{3}\right)_{3} \mathrm{Fe}+3 \mathrm{H}^{+} \\
\mathrm{R}-\left(\mathrm{SO}_{3}\right)_{3} \mathrm{Fe}+3 \mathrm{Na}^{+} \rightleftharpoons 3 \mathrm{R}-\mathrm{SO}_{3} \mathrm{Na}+\mathrm{Fe}^{3+} \\
\mathrm{Fe}^{3+}+3 \mathrm{OH}^{-} \rightleftharpoons \mathrm{Fe}(\mathrm{OH})_{3}
\end{gathered}
$$

As for anion exchanges used as a support the following reactions can be proposed:

$$
\mathrm{R}-\mathrm{N}\left(\mathrm{CH}_{3}\right)_{3} \mathrm{Cl}+\mathrm{FeCl}_{4}^{-} \rightleftharpoons \mathrm{R}-\mathrm{N}\left(\mathrm{CH}_{3}\right)_{3} \mathrm{FeCl}_{4}+\mathrm{Cl}^{-}
$$


and

$$
\mathrm{R}-\mathrm{N}\left(\mathrm{CH}_{3}\right)_{3} \mathrm{FeCl}_{4}{ }^{-}+\mathrm{OH}^{-} \rightleftharpoons \mathrm{R}-\mathrm{N}\left(\mathrm{CH}_{3}\right)_{3} \mathrm{OH}+\mathrm{Fe}(\mathrm{OH})_{3}+\mathrm{Cl}^{-}
$$

The next one is alcohol washing and precipitation:

$$
\mathrm{Fe}(\mathrm{OH})_{3} \downarrow \rightleftharpoons \mathrm{FeO}(\mathrm{OH})+\text { amorphous HFO particles }
$$

As for the mechanism, the adsorption of $\mathrm{As}(\mathrm{V})$ on the surface covered with iron oxides takes place in two stages. The first stage is characterized by a very high speed and consists in the diffusion of $\operatorname{arsenic}(\mathrm{V})$ to the adsorbent surface. The second stage, however, is much slower and involves the diffusion of the sorbed molecules into the micropores of iron oxides. Then, a structural transformation takes place on the adsorbent surface. In the case of arsenates $(\mathrm{V})$, the process of complex formation is initially connected with the formation of monodentate and then bidentate mononuclear complexes, which transform into double-core binary complexes as the degree of polymer coverage with metal oxide increases. The speed and scale of these transformations are influenced by various factors, which include the number of active sites as well as the $\mathrm{pH}$ value of the solution in which the process takes place. As a result of a low $\mathrm{pH}$ value, the adsorption process may be affected by electrostatic interactions between the arsenate anions and the positive charge on the adsorbent surface. Under such conditions, proper ligand exchange can proceed by non-specific adsorption of arsenates $(\mathrm{V})$ on the surface of iron oxides, which takes place through ion exchange with the previously adsorbed anions [30-35]. The mechanism reactions can be as follows:

$$
\begin{aligned}
& \mathrm{R}-\mathrm{SO}_{3} \mathrm{H} / \mathrm{FeO}(\mathrm{OH})+\mathrm{H}_{2} \mathrm{AsO}_{4}{ }^{-} \rightleftharpoons\left[\mathrm{R}-\mathrm{SO}_{3} \mathrm{H} / \mathrm{FeO}\right] \mathrm{H}_{2} \mathrm{AsO}_{4}+\mathrm{OH}^{-} \\
& 2 \mathrm{R}-\mathrm{SO}_{3} \mathrm{H} / \mathrm{FeO}(\mathrm{OH})+\mathrm{HAsO}_{4}{ }^{2-} \rightleftharpoons 2\left[\mathrm{R}-\mathrm{SO}_{3} \mathrm{H} / \mathrm{FeO}\right]_{2} \mathrm{HAsO}_{4}+2 \mathrm{OH}^{-} \\
& \mathrm{R}-\mathrm{N}\left(\mathrm{CH}_{3}\right)_{3}(\mathrm{OH}) / \mathrm{FeO}(\mathrm{OH})+\mathrm{H}_{2} \mathrm{AsO}_{4}{ }^{-} \rightleftharpoons\left[\mathrm{R}-\mathrm{N}\left(\mathrm{CH}_{3}\right)_{3}(\mathrm{OH}) / \mathrm{FeO}\right] \mathrm{H}_{2} \mathrm{AsO}_{4}+\mathrm{OH}^{-} \\
& 2 \mathrm{R}-\mathrm{N}\left(\mathrm{CH}_{3}\right)_{3}(\mathrm{OH}) / \mathrm{FeO}(\mathrm{OH})+\mathrm{HAsO}_{4}{ }^{2-} \rightleftharpoons 2\left[\mathrm{R}-\mathrm{N}\left(\mathrm{CH}_{3}\right)_{3}(\mathrm{OH}) / \mathrm{FeO}_{2} \mathrm{HAsO}_{4}+2 \mathrm{OH}^{-}\right.
\end{aligned}
$$

Contrary to alkaline conditions (where only adsorption of $\mathrm{As}(\mathrm{V})$ takes place), under almost neutral conditions precipitation and adsorption can be the main mechanisms of $\mathrm{As}(\mathrm{V})$ removal.

However, in the case of $\mathrm{X}^{\mathrm{np}}$-La(III), i.e., after modification, the removal capacity was enhanced by the co-precipitation and adsorption by exchange of the $\mathrm{OH}$ - group with arsenic ions. At $\mathrm{pH}$ 6.0, the arsenic $\mathrm{H}_{2} \mathrm{AsO}_{4}{ }^{-}$(about $90 \%$ in the system) and $\mathrm{HAsO}_{4}{ }^{-}(10 \%$ in the system) species are present as strong electron donors and can interact with $\mathrm{La}(\mathrm{III})$; therefore, the following reaction can be proposed:

$$
\mathrm{La}^{3+}+\mathrm{H}_{2} \mathrm{AsO}_{4}^{-} \rightarrow \mathrm{LaAsO}_{4}+2 \mathrm{H}^{+}
$$

In such conditions, the insoluble lanthanum arsenate, $\mathrm{LaAsO}_{4}$, precipitates in the acid $\mathrm{pH}$ range. As for the analogous $\mathrm{FeAsO}_{4}$, its dissolution increases at a $\mathrm{pH}$ value greater than 5.0 and $\mathrm{FeAsO}_{4}$ can decompose at a $\mathrm{pH}$ greater than 6.0. Moreover, the effect of the presence of the functional groups of the ion exchanger should be neglected. The high concentration of the functional groups only allowed a high and fairly uniform loading of hydrous iron oxide particles within the polymeric matrix. Similar results were described in [36] where the removal of arsenic(V) onto lanthanum(III) modified sorbents of (hydr)oxide type was described. Additionally, it was found that with an increase of lanthanum(III) content (within Fe/La ratio from 3:1, 1:1 and 1:3), the specific surface area of the obtained composites decreased, but the pore diameter, the pore volume and their grain increased gradually (which can be explained by the increase in the particle size and shape at the highest content of La) [36]. The Langmuir adsorption capacities of 3:1, 1:1, 1:3 and 0:1 Fe-La composite (hydr)oxides were 116 $\mathrm{mg} / \mathrm{g}, 166 \mathrm{mg} / \mathrm{g}, 235 \mathrm{mg} / \mathrm{g}$, and $368 \mathrm{mg} / \mathrm{g}$ at $\mathrm{pH} 7.0$, respectively. Taking into account the comparison of the examined sorbents and others used for arsenic removal (Table 7), it can be concluded that the high 
removal efficiency of the R-Fe-La composite (hydro)oxide makes it attractive for treatment of water contaminated with $\mathrm{As}(\mathrm{V})$.

Table 7. The comparison of other sorbents used for arsenic $(\mathrm{V})$ removal.

\begin{tabular}{cccc}
\hline Adsorbent Type & $\mathbf{p H}$ & $\begin{array}{c}\mathbf{A s}(\mathbf{V}) \\
(\mathbf{m g} / \mathbf{g})\end{array}$ & Ref. \\
\hline La and Ce-loaded orange waste gels & $6.0-9.5$ & 42 & {$[37]$} \\
La-modified ceramic material & $4.0-8.0$ & 23 & {$[38]$} \\
$\mathrm{Ce}$ oxide modified activated carbon & 5.0 & 43.6 & {$[39]$} \\
$\mathrm{Fe}-\mathrm{La}$ composite (hydr)oxide & 7.0 & 235 & {$[36]$} \\
$\mathrm{Fe}_{3} \mathrm{O}_{4} @ \mathrm{SiO}_{2} @ \mathrm{TiO}_{2}$ nanosorbent & 9.0 & 10.2 & {$[40]$} \\
${\mathrm{Mg} \mathrm{doped} \alpha-\mathrm{Fe}_{2} \mathrm{O}_{3}}_{\mathrm{Fe}_{3} \mathrm{O}_{4}}$ & 7.0 & 10 & {$[41]$} \\
$\mathrm{Nanoscale} \mathrm{zero-valent} \mathrm{iron-reduce}_{\text {graphite oxide modified composite }}$ & 8.2 & 12.56 & {$[42]$} \\
Hydrated ferric hydroxide & 7.0 & 29.04 & {$[43]$} \\
$\mathrm{X}^{\mathrm{np}}$ & 9.0 & 7.0 & {$[44]$} \\
$\mathrm{X}^{\mathrm{np}}$-La(III) & 6.0 & 22.37 & this study \\
& 6.0 & 61.97 & this study \\
\hline
\end{tabular}

\subsection{Reuse of $X^{n p}$ and $X^{n p}-L a(I I I)$}

When the equilibrium of arsenic sorption is established, the adsorbent is unserviceable and regeneration is needed to use it in a cyclic manner. The loaded adsorbent should be separated from the aqueous solution in order to perform desorption and subsequent regeneration employing an external magnetic field. The most commonly used substances desorbing arsenic ions are strong bases or strong acids, e.g., $\mathrm{NaOH}$ and $\mathrm{HCl}$.

Three sorption and desorption cycles were carried out and the possibility of reusing the tested sorbents was assessed. Sorption was conducted using an arsenic solution of $100 \mathrm{mg} / \mathrm{dm}^{3}$ and desorption with $1 \mathrm{M} \mathrm{NaOH}$. In the case of $X^{\mathrm{np}}$ during the first, second and third sorption, the percentage of sorption remained relatively constant $(66.67 \%, 66.34 \%, 65.34 \%)$. No significant decrease in the sorption capacity was noted. After the third cycle, the desorption effectiveness was $93.32 \%$ (Figure 16). Similar results were obtained for $\mathrm{X}^{\mathrm{np}}$ - $\mathrm{La}(\mathrm{III})$. The percentages of sorption amounted to $77.00 \%, 77.67 \%$, and $75.85 \%$. After the third cycle, the percentage of desorption was $90.02 \%$. This desorption efficiency can be explained by the following mechanism:

$$
\equiv \mathrm{FeH}_{2} \mathrm{AsO}_{4(\mathrm{~s})}+\mathrm{OH}^{-} \rightleftharpoons \equiv \mathrm{FeOH}_{(\mathrm{s})}+\mathrm{H}_{2} \mathrm{AsO}_{4}{ }^{-} \text {(aq) }
$$

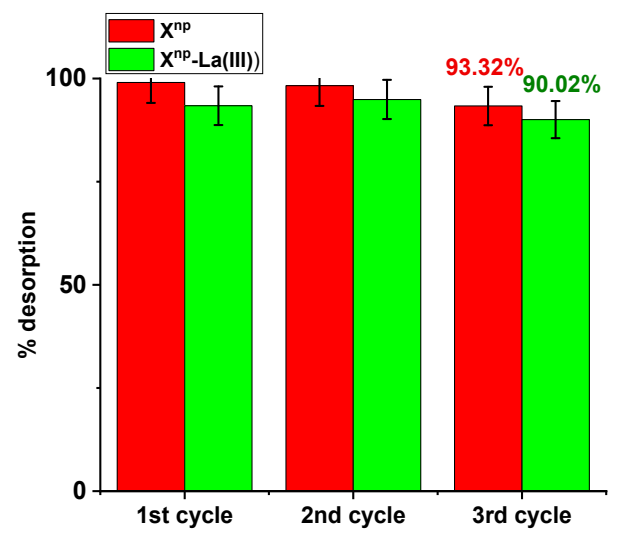

Figure 16. Desorption efficiency (\%) for $\mathrm{As}(\mathrm{V})$ recovery using $\mathrm{X}^{\mathrm{np}}$ and $\mathrm{X}^{\mathrm{np}}$-La(III) $(\mathrm{As}(\mathrm{V})$ concentration: $100 \mathrm{mg} / \mathrm{dm}^{3}$, desorbing agent: $1 \mathrm{M} \mathrm{NaOH}$, sorption/desorption time: $6 \mathrm{~h}$, shaking speed $180 \mathrm{rpm}$, temperature $295 \mathrm{~K}$ ). 
The obtained results clearly indicate that the arsenic adsorption can be carried out repeatedly on the same material after $\mathrm{NaOH}$ regeneration. The ability to reuse the same material significantly reduces costs.

$1 \mathrm{M} \mathrm{NaOH}$ was used for the regeneration of maghemite and it was found that after six cycles the adsorbent maintained over $40 \%$ of the initial sorption capacity [45]. In turn, arsenic adsorbed on granular iron and cerium hydroxide (GFC) was subjected to elution of $1 \mathrm{M} \mathrm{NaOH}$ and the recovery efficiency was equal to $89 \%$. After that, $\mathrm{As}(\mathrm{V})$ was removed with the same efficiency [46]. Another example could be the regeneration of $\mathrm{Fe}-\mathrm{Cu}$ double oxide with $\mathrm{NaOH}$. After 4 cycles of adsorption and desorption, the sorption capacity decreased by only $6.2 \%$ regarding $\mathrm{As}(\mathrm{V})$ [47]. Also the spent $\mathrm{Fe}-\mathrm{La}$ composite (hydr)oxide could be effectively regenerated using $\mathrm{NaOH}$ solution and reused several times [36].

\section{Conclusions}

The paper has proved that earlier adsorption of lanthanum(III) ions on the iron oxide ion exchanger contributed to an increase in the sorption efficiency of arsenic $(\mathrm{V})$ ions.

(a) The maximum sorption capacity for arsenic ions was almost 3 times greater after the modification.

(b) $X^{\mathrm{np}}-\mathrm{La}$ (III) removed arsenic entirely from the solution of $50 \mathrm{mg} / \mathrm{dm}^{3}$ in a relatively short time (about 2 h).

(c) It was found that after modification the sorbent can be successfully reused for purification of water contaminated with arsenic. After 3 cycles of adsorption and desorption, no significant decrease in the process efficiency was observed.

(d) Under almost neutral conditions precipitation and adsorption can be the main mechanisms of $\mathrm{As}(\mathrm{V})$ removal. After modification, the removal capacity was enhanced by the co-precipitation and adsorption by exchange of the $\mathrm{OH}$ - group with arsenic ions.

The threefold greater maximum sorption capacity after the modification together with the short duration time of the process lead to a reduction in operating costs. What is more, the arsenic removal process is very efficient at the $\mathrm{pH}$ of municipal waters. A lack of significant decrease in the process efficiency, even after 3 cycles of adsorption and desorption, enables the multiple use of the same material. All these factors confirmed that lanthanum-modified $X^{n p}$ achieves better results than unmodified $X^{n p}$ and is a very promising material in the context of arsenic removal from contaminated water bodies. The modification process itself is a great opportunity to improve the properties of iron oxide containing sorbents and to achieve the WHO restrictive limit for arsenic.

Author Contributions: Investigation S.D.; supervision D.K. All authors have read and agreed to the published version of the manuscript.

Funding: This research received no external funding.

Conflicts of Interest: The authors declare no conflict of interest.

\section{References}

1. Jain, C.K.; Ali, I. Arsenic: Occurrence, toxicity and speciation techniques. Water Res. 2000, 34, 4304-4312. [CrossRef]

2. Mandal, B.K.; Suzuki, K.T. Arsenic round the world: A review. Talanta 2002, 58, 201-235. [CrossRef]

3. Duker, A.A.; Carranza, E.J.M.; Hale, M. Arsenic geochemistry and health. Environ. Int. 2005, 31, 631-641. [CrossRef] [PubMed]

4. Matschullat, J. Arsenic in the geosphere-A review. Sci. Total Environ. 2000, 249, 297-312. [CrossRef]

5. Ng, J.C.; Wang, J.; Shraim, A. A global health problem caused by arsenic from natural sources. Chemosphere 2003, 52, 1353-1359. [CrossRef]

6. Ociński, D.; Jacukowicz-Sobala, I.; Raczyk, J.; Kociołek-Balawejder, E. Evaluation of hybrid polymer containing iron oxides as As(III) and As(V) sorbent for drinking water purification. React. Funct. Polym. 2014, 83, 24-32. [CrossRef] 
7. Aredes, S.; Klein, B.; Pawlik, M. The removal of arsenic from water using natural iron oxide minerals. J. Clean. Prod. 2013, 60, 71-76. [CrossRef]

8. Giles, D.E.; Mohapatra, M.; Issa, T.B.; Anand, S.; Singh, P. Iron and aluminium based adsorption strategies for removing arsenic from water. J. Environ. Manage. 2011, 92, 3011-3022. [CrossRef]

9. Jiang, W.; Chen, X.; Niu, Y.; Pan, B. Spherical polystyrene-supported nano- $\mathrm{Fe}_{3} \mathrm{O}_{4}$ of high capacity and low-field separation for arsenate removal from water. J. Hazard. Mater. 2012, 243, 319-325. [CrossRef]

10. He, Z.; Tian, S.; Ning, P. Adsorption of arsenate and arsenite from aqueous solutions by cerium-loaded cation exchange resin. J. Rare Earths 2012, 30, 563-572. [CrossRef]

11. Jang, M.; Park, J.K.; Shin, E.W. Lanthanum functionalized highly ordered mesoporous media: Implications of arsenate removal. Microporous Mesoporous Mater. 2004, 75, 159-168. [CrossRef]

12. Tan, P.; Zheng, Y.; Hu, Y. Efficient removal of arsenate from water by lanthanum immobilized electrospun chitosan nanofiber. Colloids Surfaces A Physicochem. Eng. Asp. 2020, 589, 124417. [CrossRef]

13. Lingamdinne, L.P.; Koduru, J.R.; Chang, Y.Y.; Kang, S.H.; Yang, J.K. Facile synthesis of flowered mesoporous graphene oxide-lanthanum fluoride nanocomposite for adsorptive removal of arsenic. J. Mol. Liq. 2019, 279, 32-42. [CrossRef]

14. Kołodyńska, D.; Kowalczyk, M.; Hubicki, Z.; Shvets, V.; Golub, V. Effect of accompanying ions and ethylenediaminedisuccinic acid on heavy metals sorption using hybrid materials Lewatit FO 36 and Purolite Arsen Xnp. Chem. Eng. J. 2015, 276, 376-387. [CrossRef]

15. Kowalczyk, M.; Hubicki, Z.; Kołodyńska, D. Modern hybrid sorbents-New ways of heavy metal removal from waters. Chem. Eng. Process. Process Intensif. 2013, 70, 55-65. [CrossRef]

16. SenGupta, A.K.; Cumbal, L.H. Hybrid anion exchager for selective removal of contaminating ligands from fluids and method of manufacture thereof. U.S. Patent 7291578B2, 6 November 2007.

17. Padilla-Rodríguez, A.; Hernández-Viezcas, J.A.; Peralta-Videa, J.R.; Gardea-Torresdey, J.L.; Perales-Pérez, O.; Román-Velázquez, F.R. Synthesis of protonated chitosan flakes for the removal of vanadium(III, IV and V) oxyanions from aqueous solutions. Microchem. J. 2015, 118, 1-11. [CrossRef]

18. Sharma, M.; Singh, J.; Hazra, S.; Basu, S. Adsorption of heavy metal ions by mesoporous $\mathrm{ZnO}$ and $\mathrm{TiO}_{2} @$ $\mathrm{ZnO}$ monoliths: Adsorption and kinetic studies. Microchem. J. 2019, 145, 105-112. [CrossRef]

19. Berhane, T.M.; Levy, J.; Krekeler, M.P.S.; Danielson, N.D. Chemosphere Kinetic sorption of contaminants of emerging concern by a palygorskite-montmorillonite fi lter medium. Chemosphere 2017, 176, 231-242. [CrossRef]

20. Hu, Q.; Wang, Q.; Feng, C.; Zhang, Z.; Lei, Z.; Shimizu, K. Insights into mathematical characteristics of adsorption models and physical meaning of corresponding parameters. J. Mol. Liq. 2018, 254, $20-25$. [CrossRef]

21. Marakatti, V.S.; Rao, P.V.C.; Choudary, N.V.; Ganesh, G.S.; Shah, G.; Maradur, S.P.; Halgeri, A.B.; Shanbhag, G.V.; Ravishankar, R. Influence of alkaline earth cation exchanged X-zeolites towards ortho-selectivity in alkylation of aromatics: Hard-soft-acid-base concept. Adv. Porous Mater. 2015, 2, 221-229. [CrossRef]

22. Alothman, Z.A. A review: Fundamental aspects of silicate mesoporous materials. Materials 2012, 5, $2874-2902$. [CrossRef]

23. Jais, F.M.; Ibrahim, S.; Yoon, Y.; Jang, M. Enhanced arsenate removal by lanthanum and nano-magnetite composite incorporated palm shell waste-based activated carbon. Sep. Purif. Technol. 2016, 169, 93-102. [CrossRef]

24. Shi, Q.; Yan, L.; Chan, T.; Jing, C. Arsenic adsorption on lanthanum-impregnated activated alumina: Spectroscopic and DFT study. ACS Appl. Mater. Interfaces 2015, 7, 26735-26741. [CrossRef] [PubMed]

25. Prasad, S.M.; Singh, V.P.; Singh, S.; Parihar, P.; Singh, R. Arsenic contamination, consequences and remediation techniques: A review. Ecotoxicol. Environ. Saf. 2014, 112, 247-270.

26. Ozola, R.; Bhatnagar, A.; Ansone-Bertina, L.; Vircava, I.; Leitietis, M.; Burlakovs, J.; Klavins, M.; Krauklis, A. FeOOH-modified clay sorbents for arsenic removal from aqueous solutions. Environ. Technol. Innov. 2016, 13, 364-372. [CrossRef]

27. Ben Issa, N.; Rajaković-Ognjanović, V.N.; Marinković, A.D.; Rajaković, L.V. Separation and determination of arsenic species in water by selective exchange and hybrid resins. Anal. Chim. Acta 2011, 706, 191-198. [CrossRef] 
28. Sarkar, S.; Blaney, L.M.; Gupta, A.; Ghosh, D.; Sengupta, A.K. Arsenic removal from groundwater and its safe containment in a rural environment: Validation of a sustainable approach. Environ. Sci. Technol. 2008, 42, 4268-4273. [CrossRef]

29. Li, Z.; Deng, S.; Yu, G.; Huang, J.; Lim, V.C. As (V) and As (III) removal from water by a Ce-Ti oxide adsorbent: Behavior and mechanism. Chem. Eng. J. 2010, 161, 106-113. [CrossRef]

30. Jain, A.; Raven, K.P.; Loeppert, R.H. Arsenite and arsenate adsorption on ferrihydrite: Surface charge reduction and net OH- release stoichiometry. Environ. Sci. Technol. 1999, 33, 1179-1184. [CrossRef]

31. Guo, X.; Du, Y.; Chen, F.; Park, H.S.; Xie, Y. Mechanism of removal of arsenic by bead cellulose loaded with iron oxyhydroxide ( $\beta-\mathrm{FeOOH}$ ): EXAFS study. J. Colloid Interface Sci. 2007, 314, 427-433. [CrossRef]

32. Grossl, P.R.; Eick, M.; Sparks, D.L.; Goldberg, S.; Ainsworth, C.C. Arsenate and chromate retention mechanisms on goethite. 2. Kinetic evaluation using a pressure-jump relaxation technique. Environ. Sci. Technol. 1997, 31, 321-326. [CrossRef]

33. Lakshmipathiraj, P.; Narasimhan, B.R.V.; Prabhakar, S.; Raju Bhaskar, G. Adsorption of arsenate on synthetic goethite from aqueous solutions. J. Hazard. Mater. 2006, 136, 281-287. [CrossRef] [PubMed]

34. Hiemstra, T.; Van Riemsdijk, W.H. Surface structural ion adsorption modeling of competitive binding of oxyanions by metal (hydr)oxides. J. Colloid Interface Sci. 1999, 210, 182-193. [CrossRef] [PubMed]

35. Vatutsina, O.M.; Soldatov, V.S.; Sokolova, V.I.; Johann, J.; Bissen, M.; Weissenbacher, A. A new hybrid (polymer/inorganic) fibrous sorbent for arsenic removal from drinking water. React. Funct. Polym. 2007, 67, 184-201. [CrossRef]

36. Zhang, W.; Fu, J.; Zhang, G.; Zhang, X. Enhanced arsenate removal by novel Fe-La composite (hydr)oxides synthesized via coprecipitation. Chem. Eng. J. 2014, 251, 69-79. [CrossRef]

37. Ohto, K.; Biswas, B.K.; Kawakita, H.; Ghimire, K.N.; Harada, H.; Inoue, K. Effective Removal of Arsenic with Lanthanum(III)- and Cerium(III)-loaded Orange Waste Gels. Sep. Sci. Technol. 2008, 43, 2144-2165.

38. Yang, H.; Wang, Y.; Bender, J.; Xu, S. Removal of arsenate and chromate by lanthanum—-modified granular ceramic material: The critical role of coating temperature. Sci. Rep. 2019, 9, 1-12. [CrossRef]

39. Yu, Y.; Zhang, C.; Yang, L.; Paul Chen, J. Cerium oxide modified activated carbon as an efficient and effective adsorbent for rapid uptake of arsenate and arsenite: Material development and study of performance and mechanisms. Chem. Eng. J. 2017, 315, 630-638. [CrossRef]

40. Feng, C.; Aldrich, C.; Eksteen, J.J.; Arrigan, D.W.M. Removal of arsenic from alkaline process waters of gold cyanidation by use of $\gamma-\mathrm{Fe}_{2} \mathrm{O}_{3} @ \mathrm{ZrO}_{2}$ nanosorbents. Hydrometallurgy 2017, 174, 71-77. [CrossRef]

41. Tang, W.; Su, Y.; Li, Q.; Gao, S.; Shang, J.K. Mg-doping: A facile approach to impart enhanced arsenic adsorption performance and easy magnetic separation capability to $\alpha-\mathrm{Fe}_{2} \mathrm{O}_{3}$ nanoadsorbents. J. Mater. Chem. A 2013, 1, 830-836. [CrossRef]

42. Akin, I.; Arslan, G.; Tor, A.; Ersoz, M.; Cengeloglu, Y. Arsenic (V) removal from underground water by magnetic nanoparticles synthesized from waste red mud. J. Hazard. Mater. 2012, 235-236, 62-68. [CrossRef] [PubMed]

43. Wang, C.; Luo, H.; Zhang, Z.; Wu, Y.; Zhang, J.; Chen, S. Removal of As (III) and As (V) from aqueous solutions using nanoscale zero valent iron-reduced graphite oxide modified composites. J. Hazard. Mater. 2014, 268, 124-131. [CrossRef] [PubMed]

44. Lenoble, V.; Bouras, O.; Deluchat, V.; Serpaud, B.; Bollinger, J.C. Arsenic adsorption onto pillared clays and iron oxides. J. Colloid Interface Sci. 2002, 255, 52-58. [CrossRef] [PubMed]

45. Lin, S.; Lu, D.; Liu, Z. Removal of arsenic contaminants with magnetic c $-\mathrm{Fe}_{2} \mathrm{O}_{3}$ nanoparticles. Chem. Eng. J. 2012, 211-212, 46-52. [CrossRef]

46. Zhang, Y.; Dou, X.; Yang, M.; He, H.; Jing, C.; Wu, Z. Removal of arsenate from water by using an Fe-Ce oxide adsorbent: Effects of coexistent fluoride and phosphate. J. Hazard. Mater. 2010, 179, 208-214. [CrossRef]

47. Zhang, G.; Ren, Z.; Zhang, X.; Chen, J. Nanostructured iron (III)-copper (II) binary oxide: A novel adsorbent for enhanced arsenic removal from aqueous solutions. Water Res. 2013, 47, 4022-4031. [CrossRef]

(C) 2020 by the authors. Licensee MDPI, Basel, Switzerland. This article is an open access article distributed under the terms and conditions of the Creative Commons Attribution (CC BY) license (http://creativecommons.org/licenses/by/4.0/). 